体

像 G

に

迫 $\mathrm{H}$ は

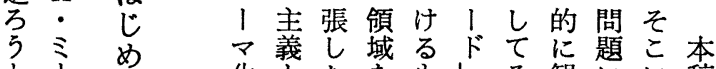

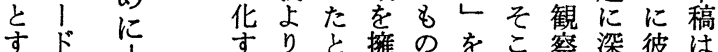

るの すす す

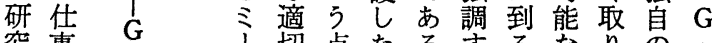

究事 $G$ । 切点たるするなりの.

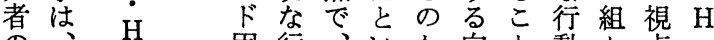

の、. 固行、心か向と動ん点.

作死 $ミ$ 有動心う、きを汇をミ

業後门の琵点とも主の研探门

を半ド義学でい、張み究るド

通世纯の、う昨すを者試の

し紀と石を自個問今る扱とみ仕

てた社㢳然人題です方

不会開科のはは法とてあを

断今的行学内禾論い主る捉

にも行 ブう志経議論ア方クミ

再議憅至尚験論議 プ法品にそ

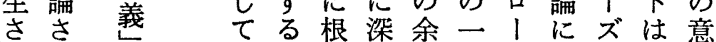

れれ 浮ミざく地方于対アシ義

$\tau$

きそ

たの

がす踏をにとしッンを

感 全

びドワみ残見してプボ理

上のト込しるて、さり解

が論ソんてて客れ般客てし

てをのいるがに観き・い

お糊かが来辿客っよで知にたイく

けとのあるる観たらきら観をンた

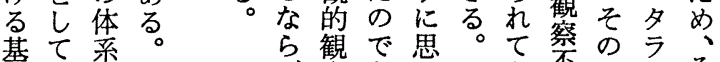

礎 い方有

的 る不名

知こ明な

識 と瞭 自

のにで己

二よ部っる 論

と $こ こ \vec{I}$

な \&

て却にと

いさつ $\vec{M}$

るれて $\mathrm{M}$

むる る

ば察もわだき不二クそ

哥なれがた可能方手

社能ける。ここなで 手

的のば社うのす た

行要、会し重の、トり

動求ま的た重!彼等と

主をた行荺性観動的にし

義引観動だ指な祀よて

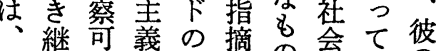

わい能に主しし的最の

れだなよ張市行軼社

わの\&つが社強動積社

れでのて彼莝誈墔極会岩

し ま 概

ろなた概

し、そे

ば今概そ

ば現規れ

指帒定含

摘社 が含

れ学昧何

てに模 ら

のむ相な通ミ仕行し義的行

相な通、集行動観が言憅 城

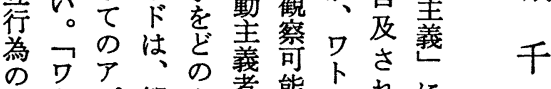

プト プ観よ者能ソれ、焦早

セン1祭にしもの自点

スのチ可性ての見を

ま行を動主な格の通客観の市

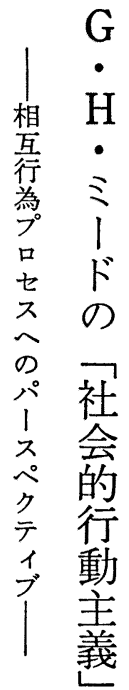




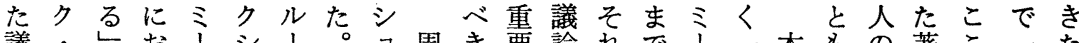

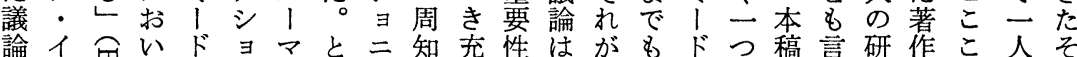
をン宾てのニ 展夕寻鍵思スにわ厶通なの決门く有手こる者な潜き瞹 開ラ@と想卜よけのり余かしドくの掛のだとい在す眣

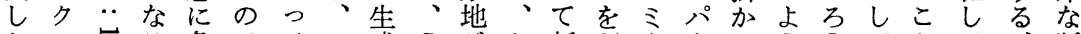
たシ苋る負アてシ成 $\mathrm{G}$ がと新理 | I り ううてとて、、断 研 $ヨ$ 主つプはンの.あいし解ドスとな。のといと片

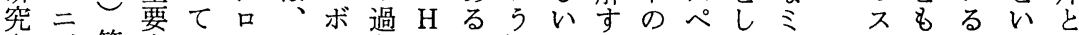

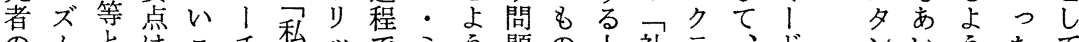
の㕕と注るチ私ッでミう題の上社テ、ドンいうたて

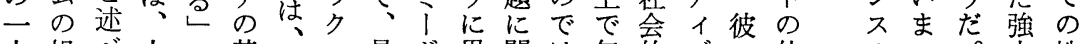
人祖べ人○基他・最ド思関は無的ブの仕のうっ力性 と、ら間芯礎のイ\& のわしな視行を事把てそさ格 しまれが寻を誰ン積仕れていし動探社を握、しが流

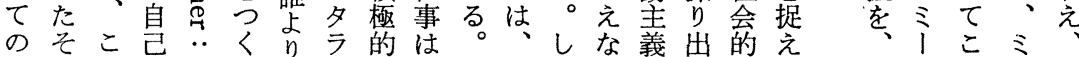

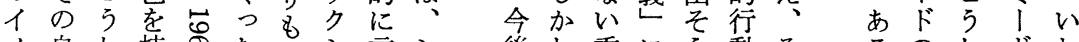
メ自し持寻た、シ言シ 後し重にう動そそるのしドわ

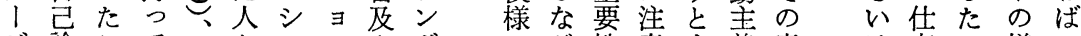
ジ論こてなとンニさボ冬が性意す義意は事こ様コ

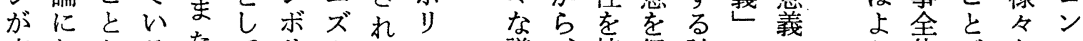

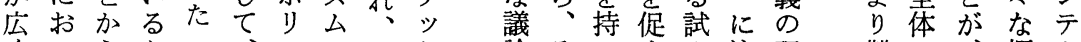
くいらとマ、ッの評ク 論そつすみ注理、難の、概ク 定て、心ミ主ク提価: 唯れて議で自解等眺彼念

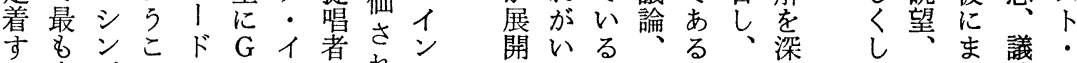

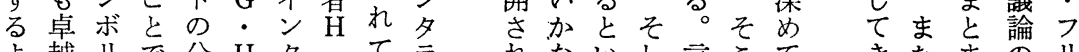

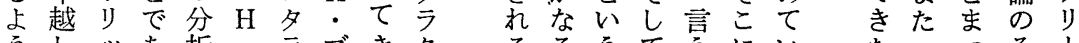
うしッあ析・ラブきクるるうてうにいるた

れ議経い義もうらそのの会るであの吃をラ D 調に

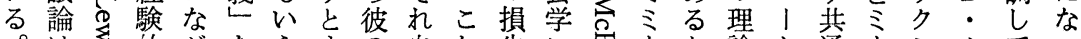

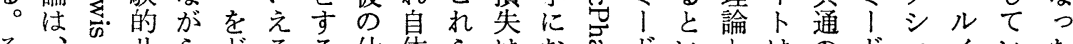

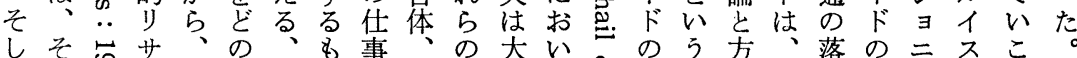

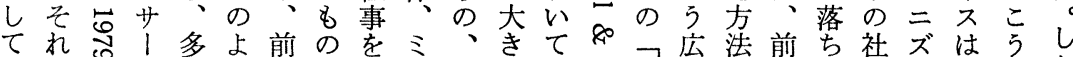

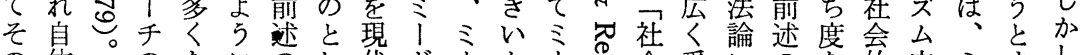

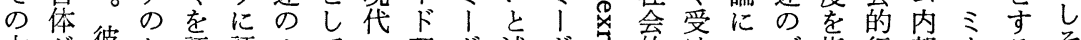

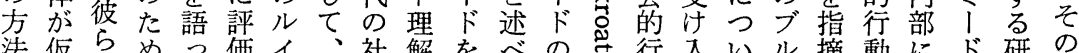

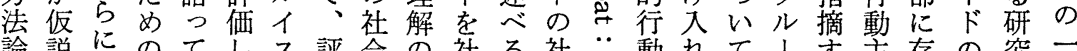

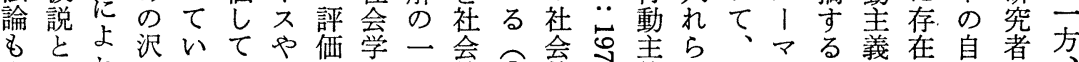

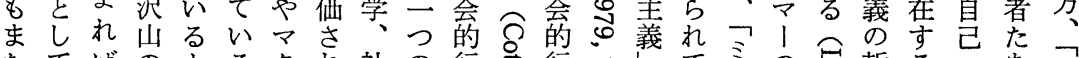

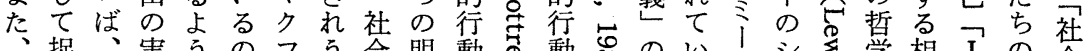

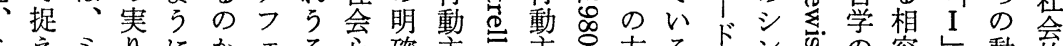

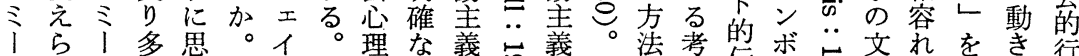

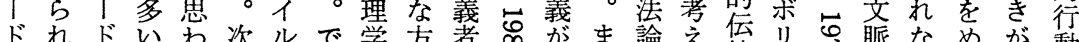

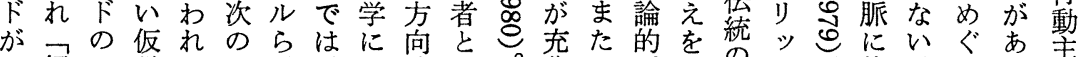

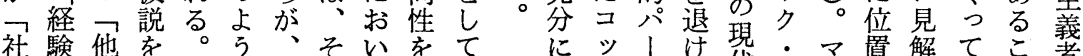

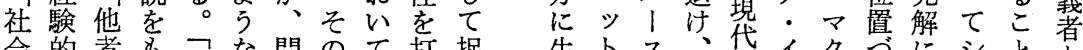

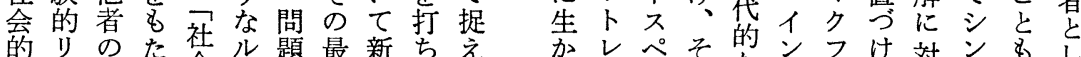

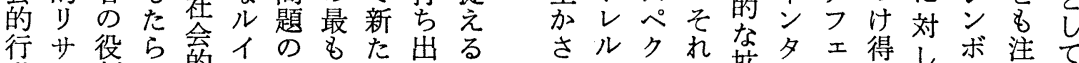

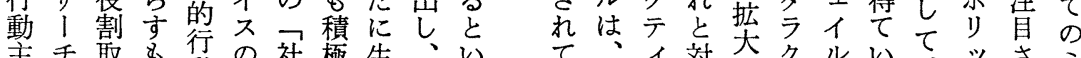
主手聚名㗢の社極生、いて、ィ対大クルいて、ッさミ 義し得の動言会的かそ5

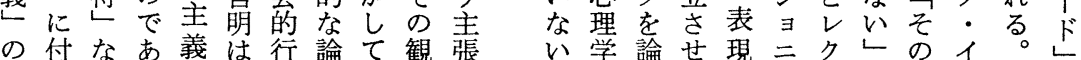
もせどるは、動者い点はなた岕るしズルと概ン Jを とらのし、短主とこか、め社る形でムスい念タ! 強 


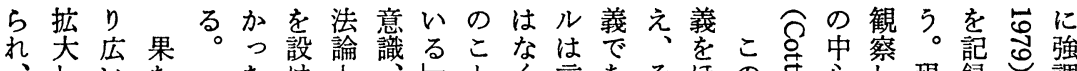

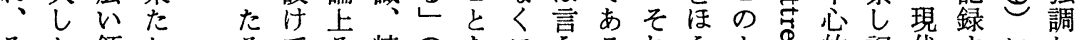

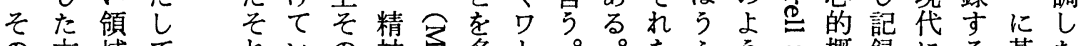

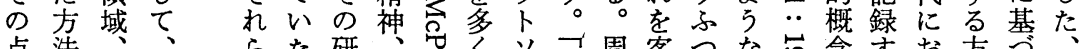
点 法

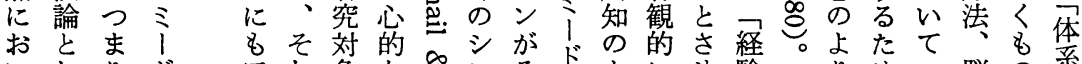

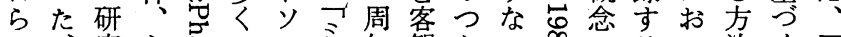

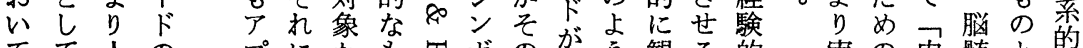

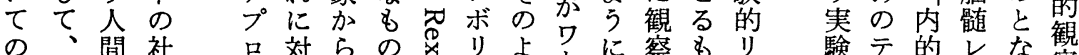
みま間社只対 5 の 評た内的 価実 的 行

さ験な動

机的 $7^{\circ}$ 主

うリ口義

るサセは、 8 1 开古 でへ\& あの 含ソ

ろ扉むン 5 と 領 の 加㫐域行 ミ、適憅 了性角義 ケ格す 志 チて外い离クな? ミるが! のミしっ

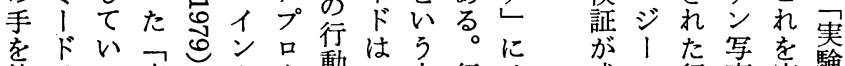

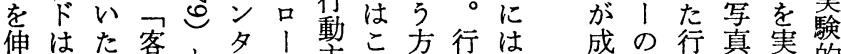

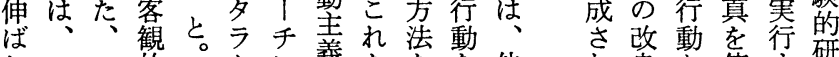

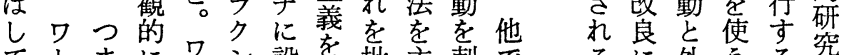
てトまにワシ設を批主刺でるに外引る究

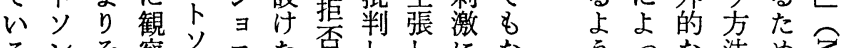
るンそ祭り三た否ししにな ううな法め及 がの奀ンス限してた対い取宁可はて行架、气

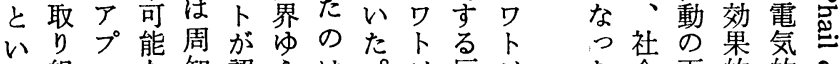

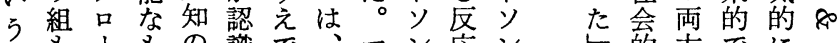
わ毛8の識で、マン応ン的方でにす

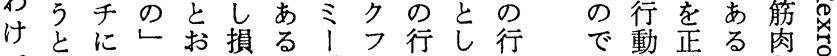

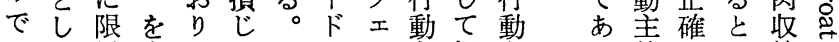
仕けくよあな界方、てこでイ主捉主る義にい縮・.

産で彼は

あ゙て

るた 岕方議そし

自ンシ論の自

它ボまた自む

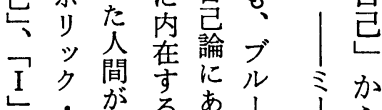

とイ方例っ 占ら

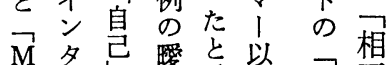

$\mathrm{E}$ 亏 晽言来自丝

をシ持さでミ芑荇為

概 $\exists つ$ 良门概 プ

念二こるいド念口

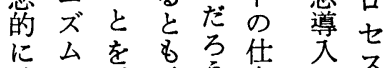

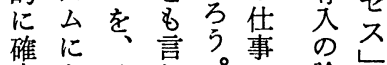

定とそわれ゙に論へ

してて立る理产

くミ論々琵る

くミ作卡㞧の議

業ドく芯端の

はの遗識名第焦
い性、のてるンがに己る度てこ事 。格ド社異このでワしこ問批とに と独会質と行き卜のとい判でお 自的なに動るソ議が、しあい 相の行もよ主かン論でミ、って 互仕動のつ義らのにき! あた行 行為方義しさとを゙行一るだるの 社 プテのてらる辛立のつは。的 口1 パ論にい。義 七マ 、 じく第と帰思会襲れ動 ス化スて社つ三のるわ的すは主 へすぺい会かに結。れ行る、義 のるクく的のは節なる動もワ兄 アもテ。行角、点ぜ。主のトを プのイこ動度ミとなそ義でソ主 ロでブれ主か1もらの热あン張 1あがら義らドいばたのるの等 チる、のの比のう、め意の行る のこ相作論較社べそに義か動こ 視と互業理検会きこ本を。主と 角を行をを討的議か稿新こ義は を指為通、す行論らでたれを

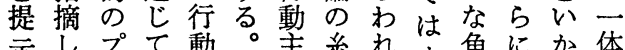
示し、゚て動こ主采れれま角にか体 てそ七最義のとを我をず标いるを ての不後と作、迎は彼らて点主 い固をに澲ワる、の検、に張

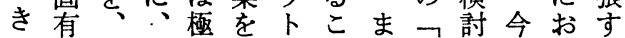
たのミこめ経ソとさ自すーいる 


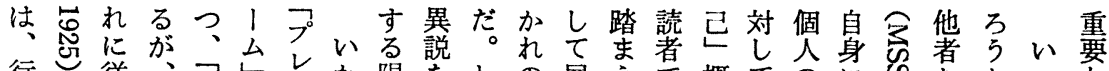

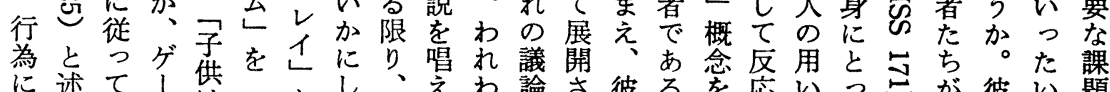

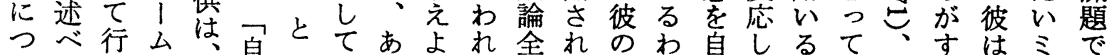

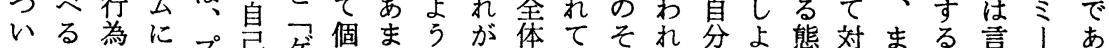

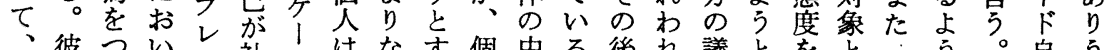
彼ついイ社么はなす個中る後れ議とをと的う。自ら よはかてに会ら自いる人ですのは論香措な自に彼身る

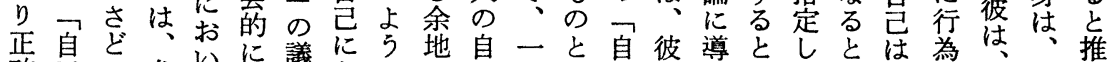

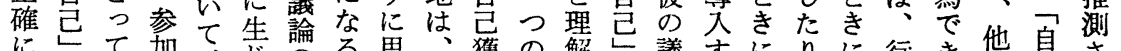

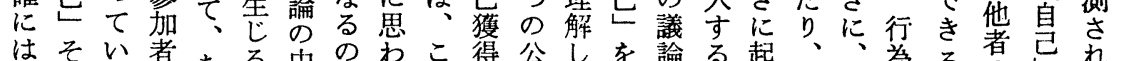

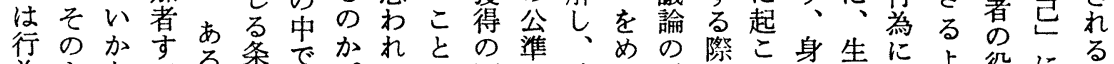

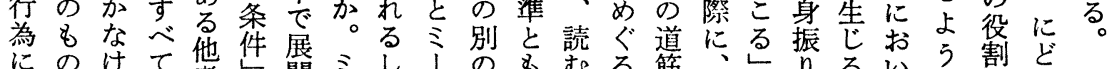

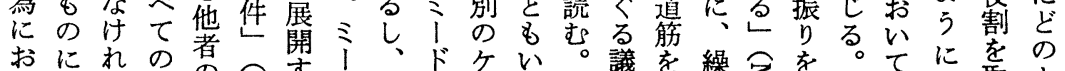

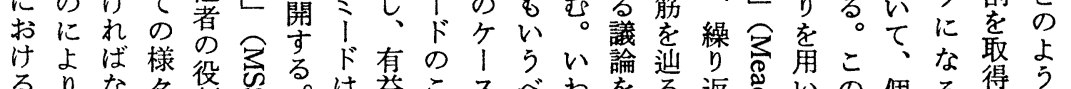

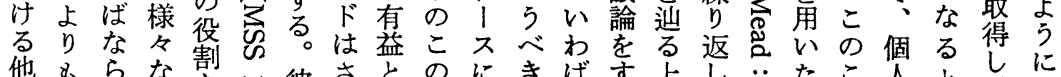

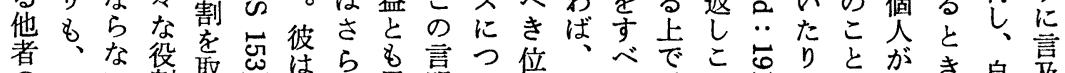

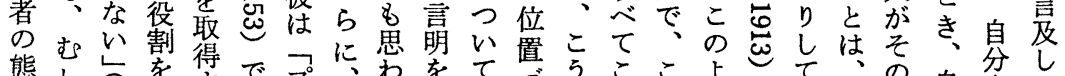

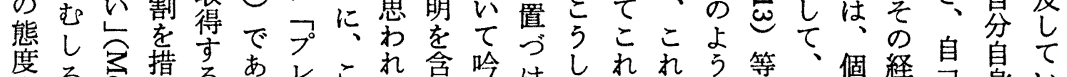

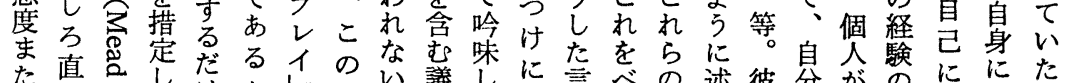

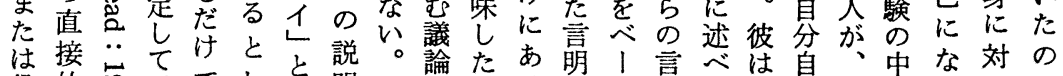

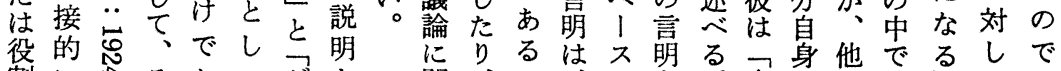

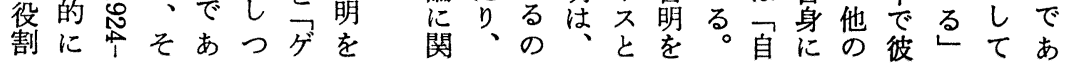

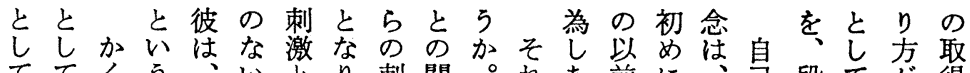
てく5、かとり刺関。れあ前に芑段てが得 受受しこし相な、激連個でらあ他個は階ミ間の

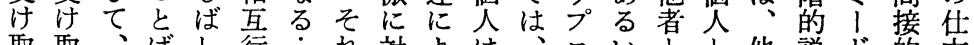
取取、ばし行京れ対よは、口いとと他説ド的方 りり個にば為 ににしつつミセは行他者明がにに

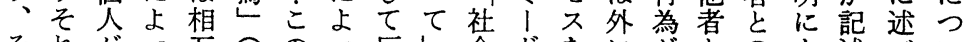
それがつ恶のつ反会ドをに学とのよ述べい れに自て行命よて応行的は見、あの行つ守らて に対已記為气う引监為なこ据簃る行為てるれ言

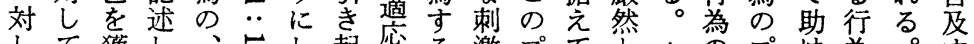

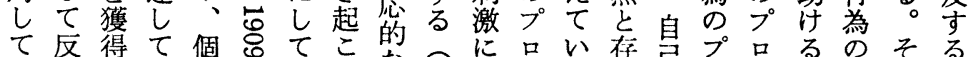

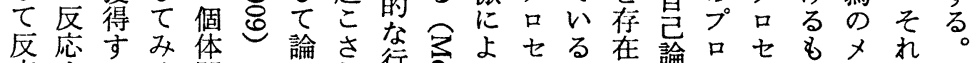

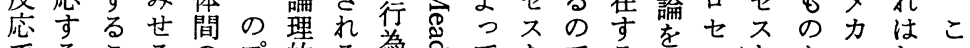

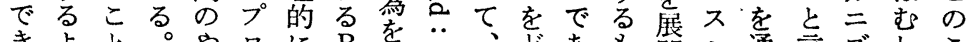

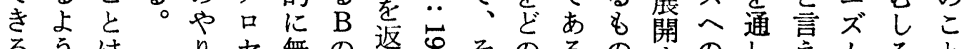
る

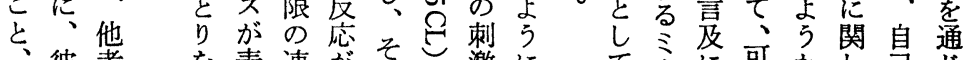

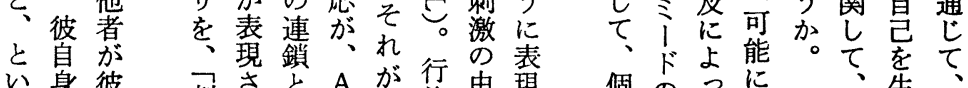
い身彼刺さと $\mathrm{A}$ が行由現個のつに

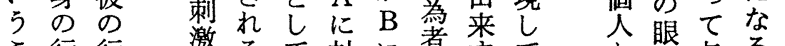
こ行行激るて文に者委て と眼与る。

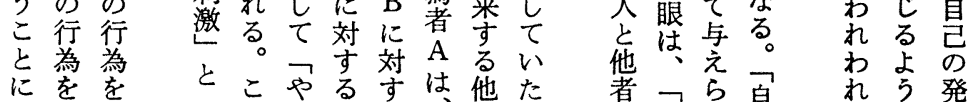

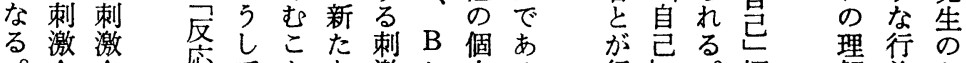
- A A 応て之な激か人乃行全。概解為あ 
で提上力で何除がはもる科ともて配今 で行 はのうはあか故で、そ。学反岁、禁現口あ動さへ 、結な、る、べき共のあ化応..刺るにトる主てし

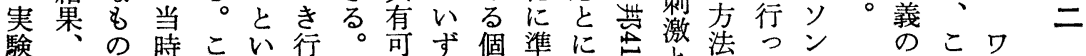

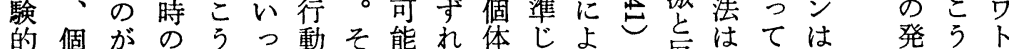
に々あ内したをしなものて孝市何い

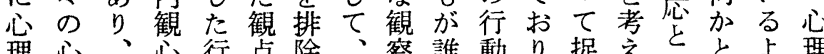

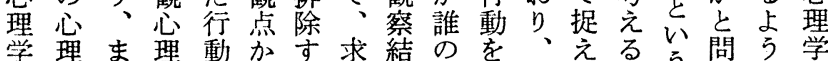
学理ま理動加す求結のを眼をるるる。う問ら学

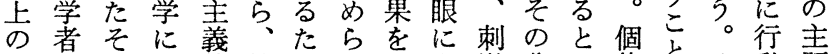

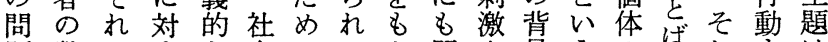

題数はす心会にると同 A 景うの就すすは に取同観批学題除動に様に対はでら行翻て、る行 り数に判をにすを個観すするこ䚿こかで

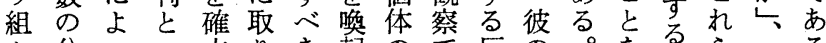

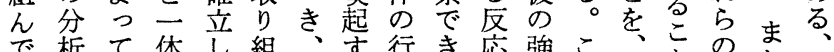

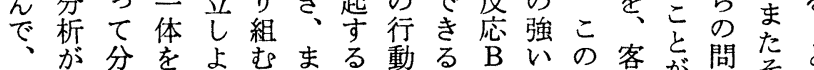

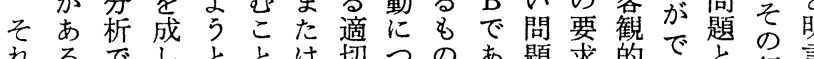
れるでしととは切つのあ題求的で点行言

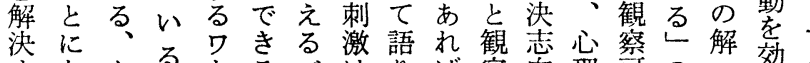
すなとる。るべはりば察向理可引決果々 がワ

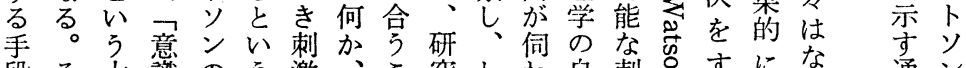

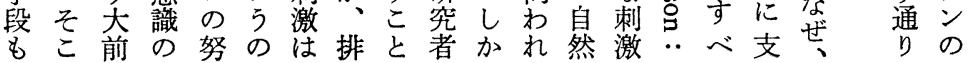

ドのをはたし、主も のよ不還。、義深し 言つ適元そ対はいか うて切しれ象、部し ᄀ立でえゆを心分な ワつあなえ客理にが 卜基るい、観学まら ソ盤と人も的ので そす間しに自触ミ ののるのそ観然れ、 行もな領れ察科てド 動のら域に可学いの 主にばが対能化なこ 義抵、あしなをいう よ触そ るてて す もる主と客にすにワ 適も張を観限ゆ思 卜 切のは強的定えわり なで、調にしにれン む 既し観よ刺る批 行るに、察亏激 $\widehat{1}$ 判 動。ワそ然と! 。は

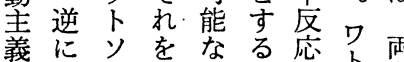

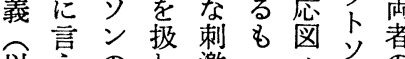
以えのわ激の式光の 卡行なやでをの想 れミ憅し応あ援行違 を门義とへっ用動最
る的察卜心 心切態トにト動もな な哥り的心れ度ソ、ソこ琵心

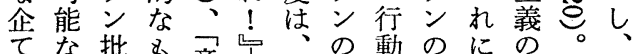
をな批を意门可そ集行対心彼多 拒激のを識々不れ義動し理は数 否と中ををん思よを主て学この し反心無あな議り自義ミがの方

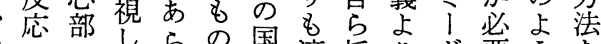
観にでしらの国適採りだ要うを 察固あてゆ存了切角適はだな標 祭きあいる存了なす切言と不蕉 可換るる念在りるるなら論毛化

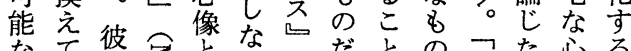

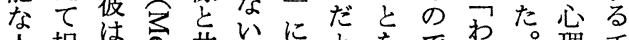
人捉は串共い。登と起でわ。理手 間充お范心登い述あれわ学段

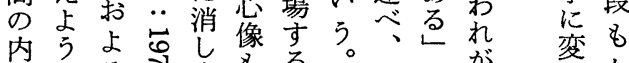

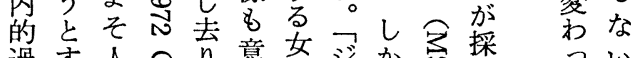

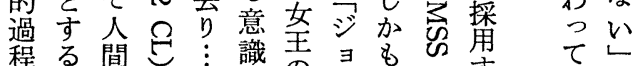
程る間も

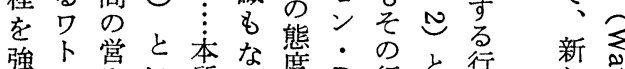

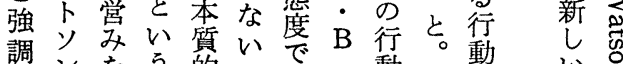
すンをら的のあ・動彼憅いる

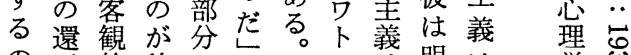

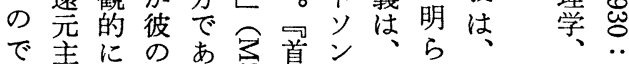
あ義観ワる悹をのワかワ行率 


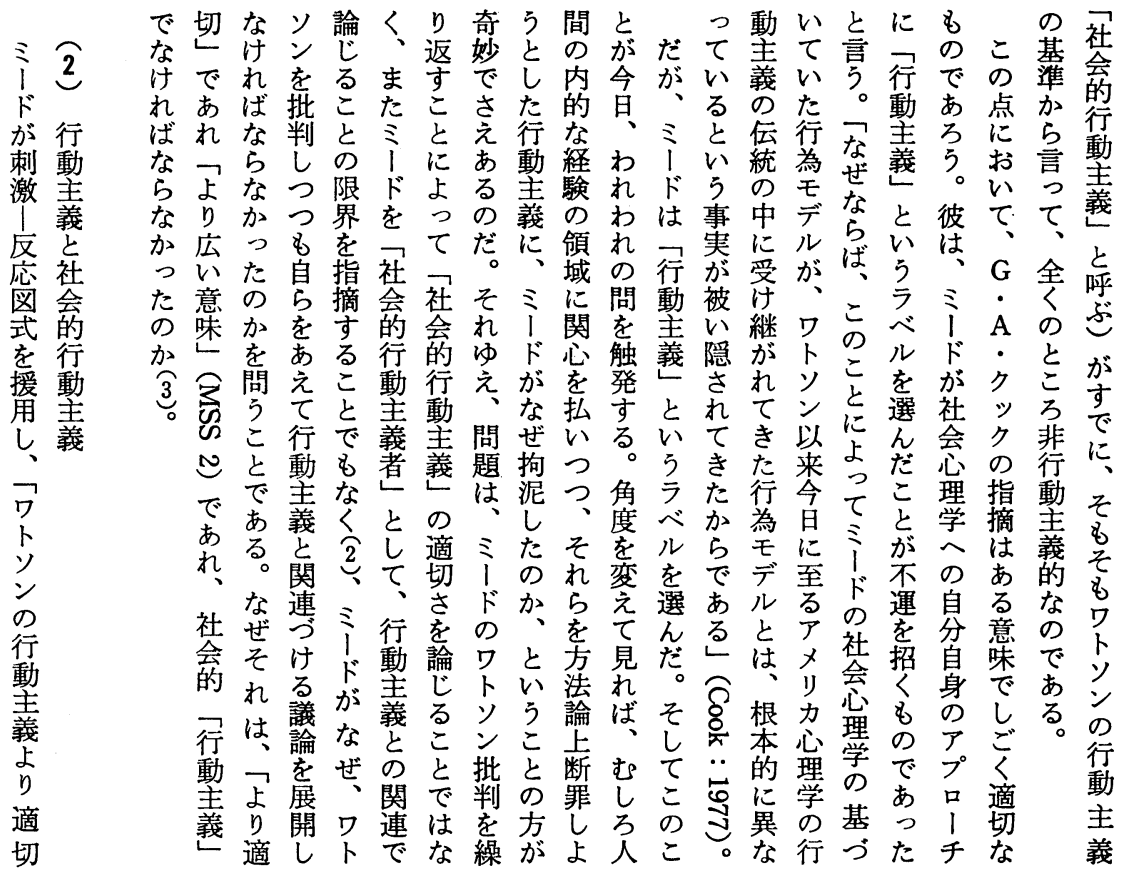

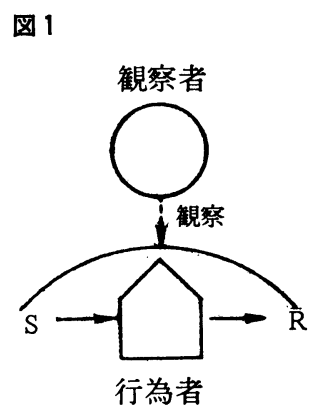

国 2

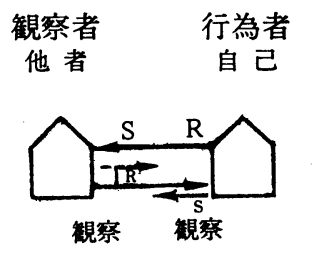

観の行てでりて観す者 ワプに 者為観まるでのあト।の域考主社 の者有察た刺あはるとチこをえ義会 方に益の観激る、いンにと対なと的

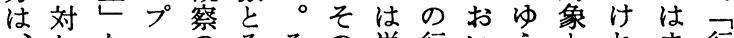

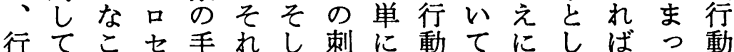
為特と続にて激有主、椾なた主 の権でおき対ワと機義両刺含らく義 主的あよがす卜反体は者激めな異热 体なるび明るソ応を、のをるいなを を立。そ示反ンでま刺論受か。る語 観場さのさ応にあず激理け否両フる 察にら結れの従り措をは反か者レ時 の立に果て客え、定受深応との|に 客つ、のい観ばそす怙くすい相台は 体てこ共る的、れる、異るう違に といの有な観こら。反な行レはおそ しる場化ら察のを行応つ為べ、れ て。合㤎ば哥と捉動垱て者ル刺ては め権 観能複性、る義こるまと・解卜 る的察で数が行方者す。たど区すり のと者あの保為法が主そま応るン にははり観証者は研体のらら必の 対、常、察さに、究で行な還要そ

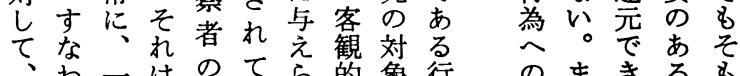

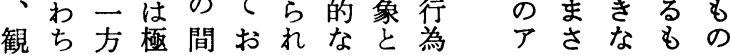


す起に互時主のは住口行にをる者と義た样こる。動とら るこ反行に第義こ、、七為お観こにいう様こ。主いれ プす忘為措—のと観こス者け察とようう相れ観義うる

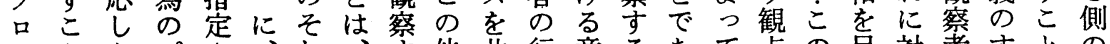
セとあプさ、れ、等他共行意るあて点の呈対者すとの スでい口机かミる者有為味他る観か広ししはべで行 の他、七る為ら!他にし学著し察ら、いてて彼てあ為 た方他スだ者際ド著よう射のがそさ、意い、ののる 者 だに方にけと立ののつる程、同㐫れそ味るミ語議。の 中刺の共で他た社存て他内行時心るれで。! る論ま方

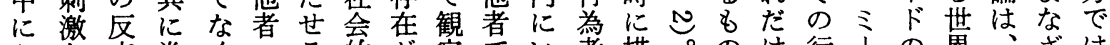

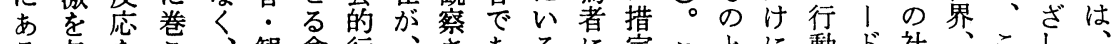
る年をこ、観含行、等あるに定ことに動ド社、こし もえ刺ま相察意動行扎る他対さこし限主は会行の朔逆 のる激れ互者省為る。者すれでてる義論的為特、に

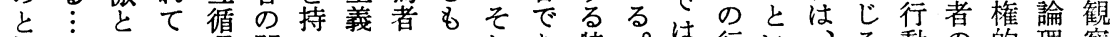

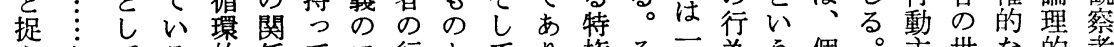

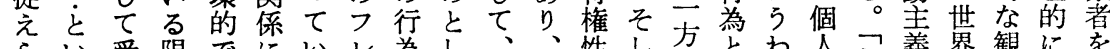
らい受限でにいレ為し、、性し方とわ人う義界観にを れうけりあつる।のて社行はて隹けの的のの察はど る。例とにるい厽前の会為備こ行 5 で経わフ外者常ら

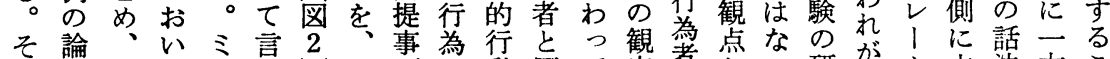

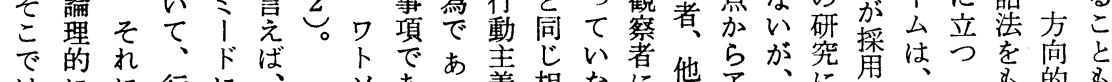

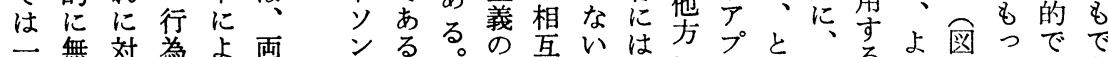

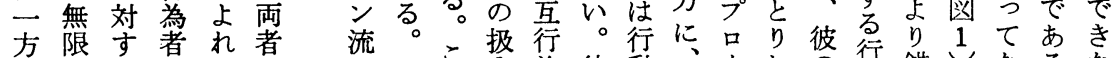

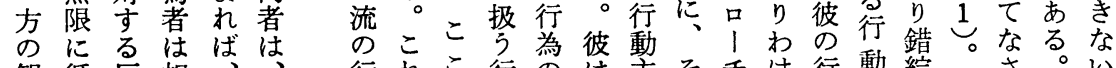

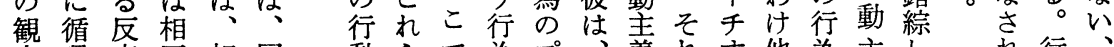
察環応互相同動らで為プ義れす他為主しれ 行

こくな観義第身吾受返で適す导身こは辿る。第れ察者

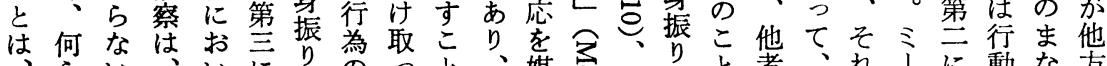

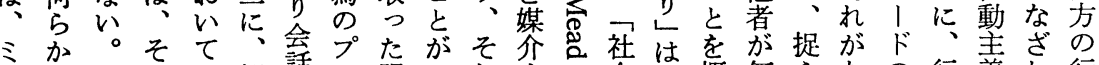

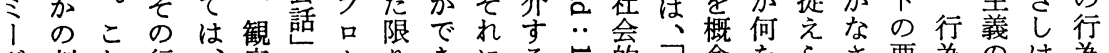
ド刺れ行、察奇きにる。的社念をらさ要為のは為

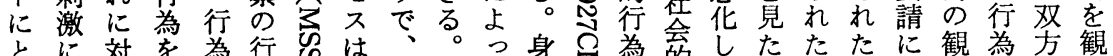
とに対を為行怘は为会したたたに観為方観 つ対し、注為、出行て振包行てか行相従察者向察

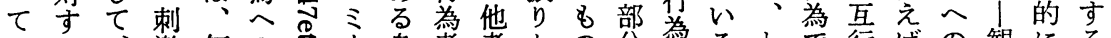
はる、激何の预身者者との分為るとで行ばの観にる、 そ応、A ら のとド\&のにのよと振初他てり、義、問。プ会性関すい 行しもと刺つでれしりの者、㩘ミを行口的、係るう 為て、で激いあばては行が社そに!通為セ行ととも関

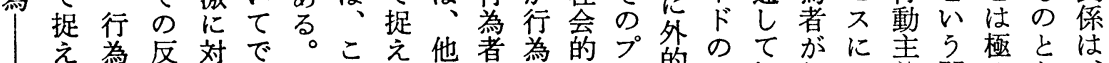

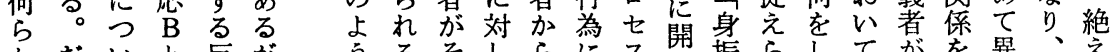

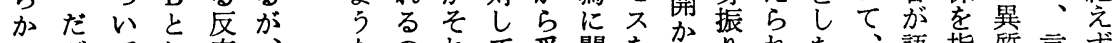
のがてし応なのれて受関を加りれた、語指質言ず

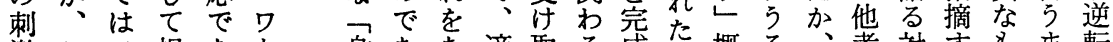
激こワ捉あ卜身ああ適取る成位概る、者対すをを転 A れトえり、ソ 振るる店っ個守相念もと象るのでし

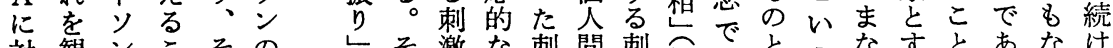

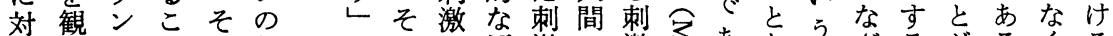

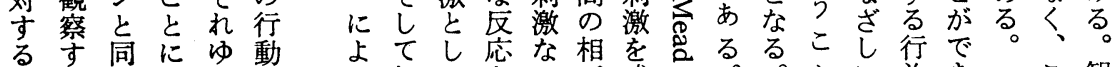

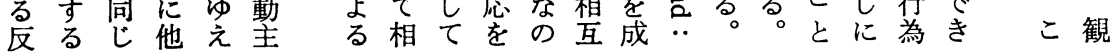


う措触 至為調仮い互に振対得思そに自互のと行動応 と定れ后者す定うい注りわすいれ対导循こそ言動主 $\mathrm{B}$ すすた。はる、層に意会れる起にしを環として主義

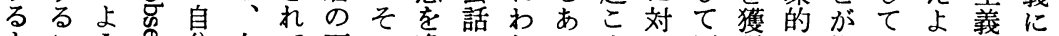
もこ5分人て下の喚のれるすし反得で指再うにおる のとに息間いに関起わの特必て応すあ摘び。おい新

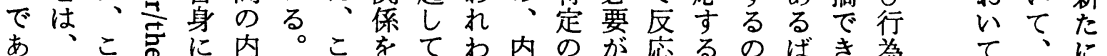
るワう。対的それ逆おれ的人あでよがかる者注行刺

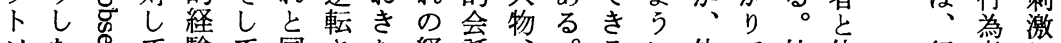
ソたすて験て同さた経話通さるに他で社他行者 $\mathrm{B}$ ン層』、の、様せい験觜まこ彼者な会者為のと

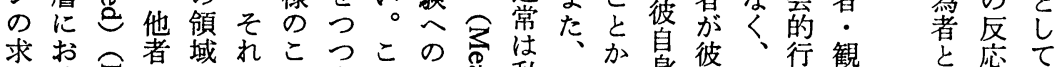

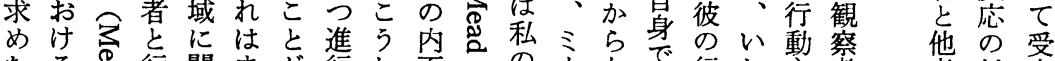

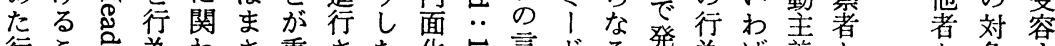

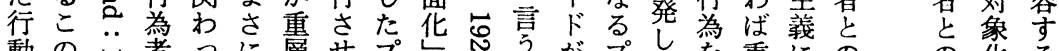

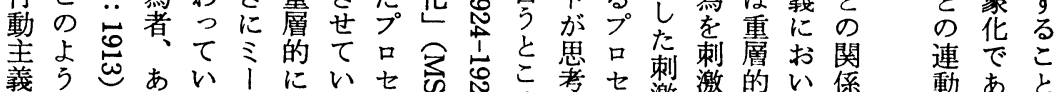

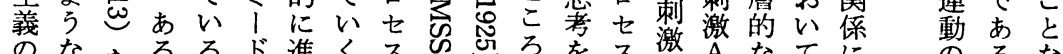

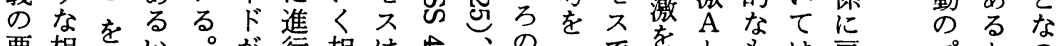

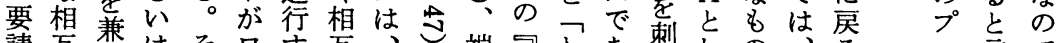

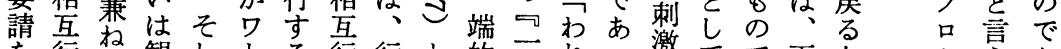

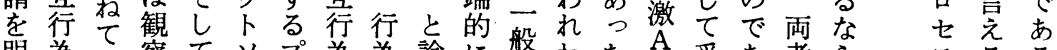
明為い察てソプ為為論に船わた受あ者らるるるる

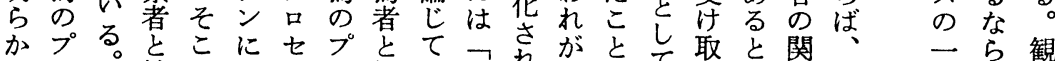

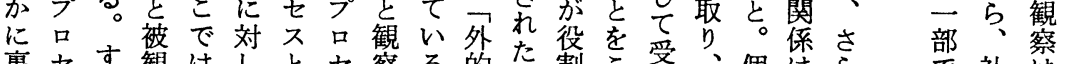

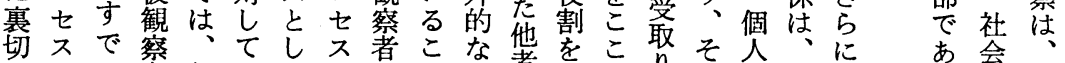

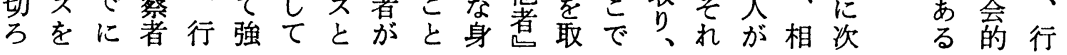

求問いド観え論うが為行プくワと学乃両為行

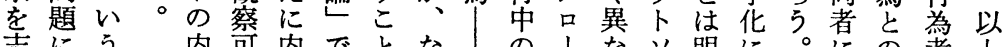

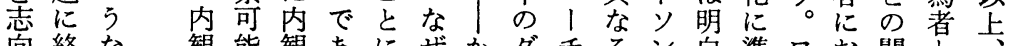
向終な、観能観あにぜかダチるン白淮ワお関と、 さ始れ法な法るつてらイがものでじト係他ミ せ垫批もをとい観出ナ行の言あてとると者门社

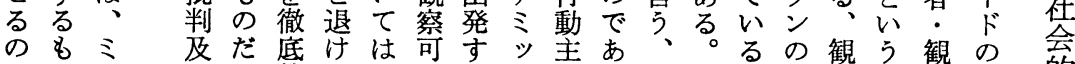

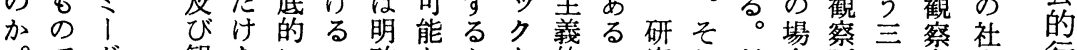
。でド観をに確なとな的こ究した合祭う者会行 そはの祭扱批令に活い社でと者てが只能のと的動

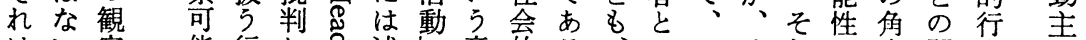
は、察能行し、..述意的る、いミそれ渡関動義

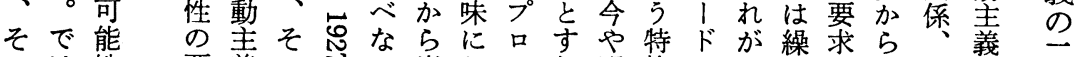

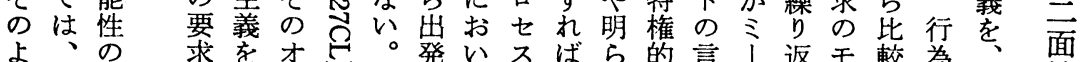

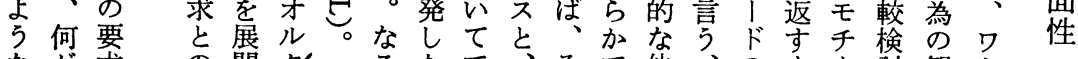
なが求の開ダだるなで、そで他、のま、詂観卜 方彼の結しナがほけあそれあ著他要でフし察ソ 法にモびたテ、、どれるれはるに者求もをてべン 論そチ付こイ゚ワ彼ばとを観。よに市な考きのの のの、きとブトはな述構察ミるるるく察た関行

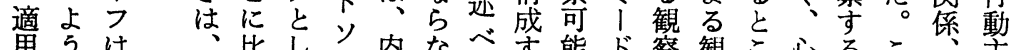
用 5 は、比しソ内なべす能ド察観こ心るこ 、主 さな直尔でか観いるるなは可察ろ理必こ逆義 れ方方接れ、が法の乞社活、能哥で学要でにと

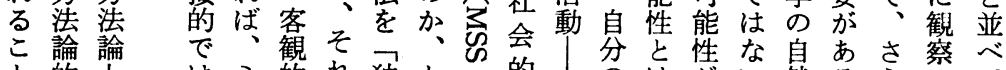

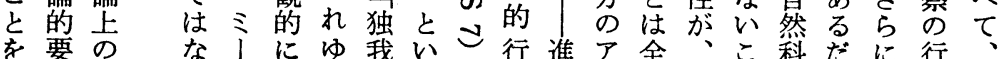


のれ状の气に行け彼は初筆し者う表為のわ口ロらと待

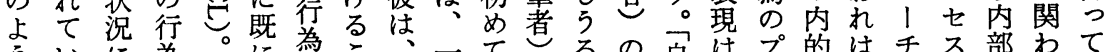

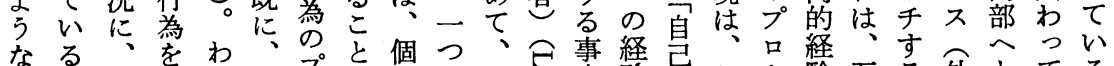

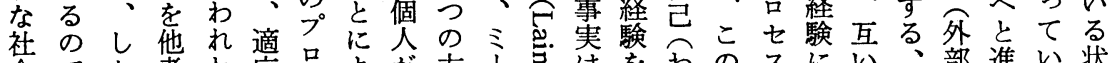

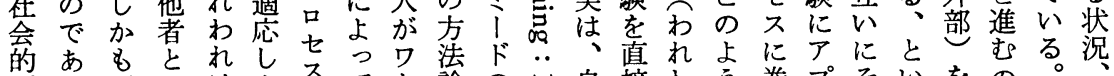
プる互いはよ不て論の、息接わう卷プそいをの

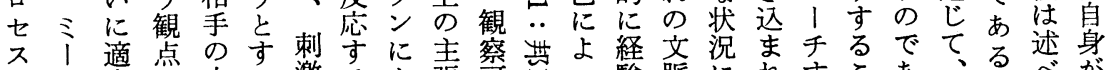

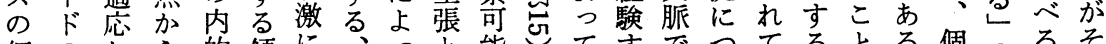

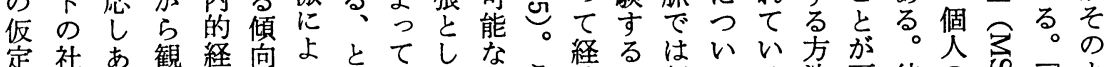

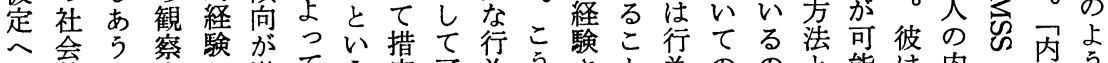
と的と繁に潜てう定了為うさと為ののと能は内肉部う 導行いるアん開わさ解のしれはのイだしなこ的の部に

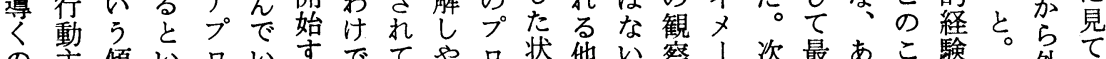

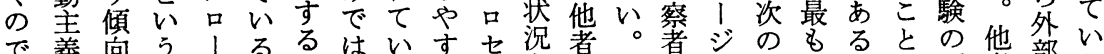

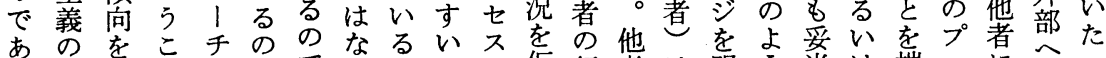
る主内としででいよもか仮行者は奛ら当は端口に、、

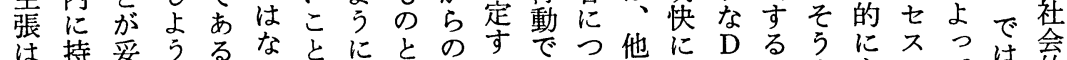

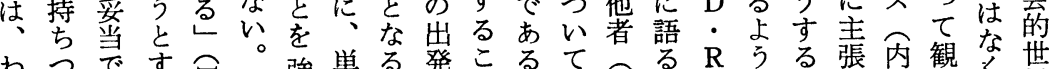

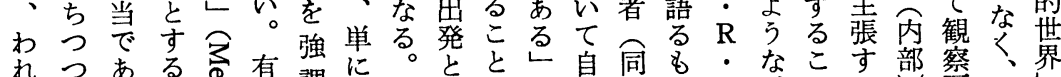

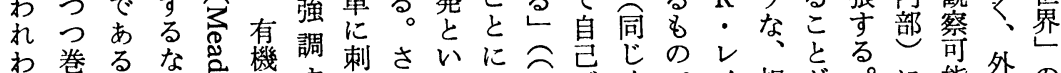

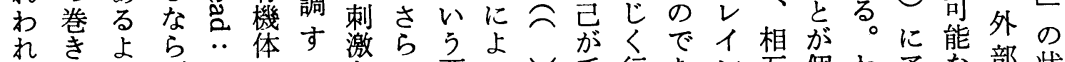
を込

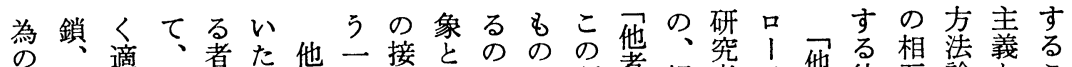

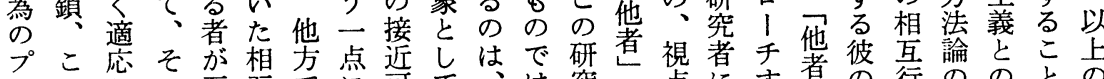
口こしの互互でに可て、は究に点にす者学行ののと市 セにあ刺い行はか能個行あ者に学対るに基為提対がこ ス、っ激に為加性人為りのは取しいよ本の起比でと をわてに相のこつは、者え視こ可てこて認プでにきか

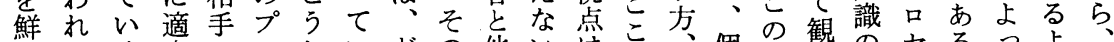

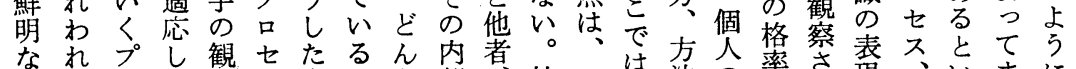

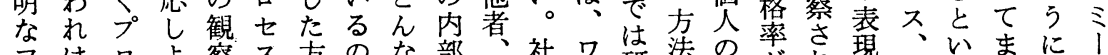

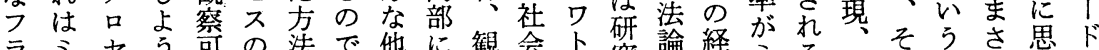

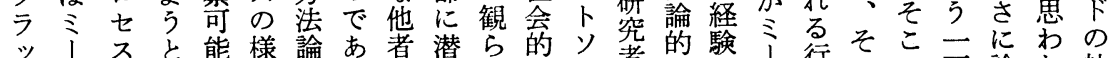

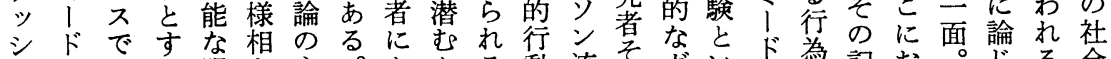

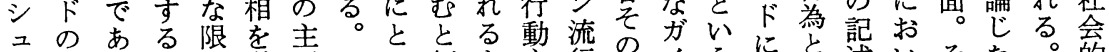

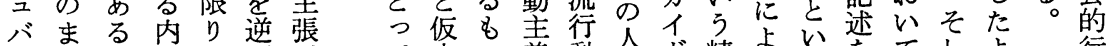
ッな。なで照がてて定の義動がド精よ゙ちをてしよ一行 クざこるの射

としう傾行亦わ しがし向為るれ て捉たのも。わ 見え行 \&しそれ るて為とくれに こいとにはは、

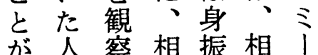
で間の 互り互ド きの無適をにが る相限応を行捉

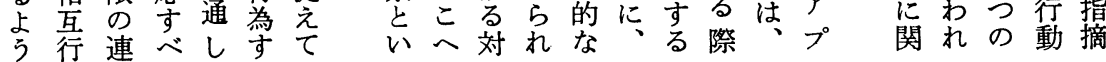
もさとの主含ラ妙つ鹳成わてうつ動 れ観フ義意イな述点すれ今には竞

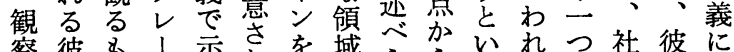

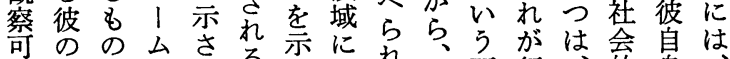
能経のにれる。示予れた個面行る的身

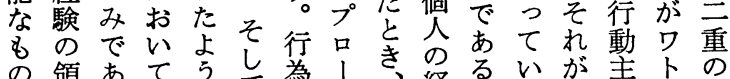

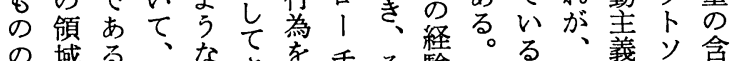

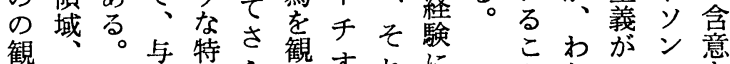

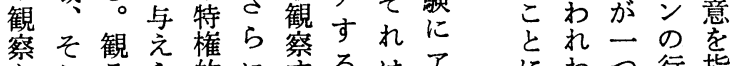


動批い人の激可は内間もな観う者をりあすれことに 主判。間方と能、的にしど察領に相と口りるたとい思

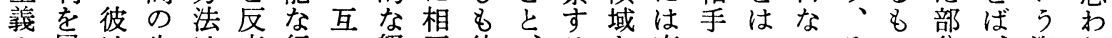
の展は生は応行い経互彼るを直のいのその分、資れ 方開、き、之為に験行㤎普限互接すえ的のでで遠格る。

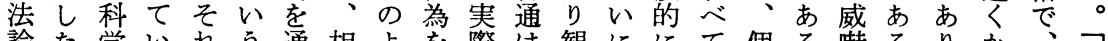
論た学い扎う通相よ学際は観に仮はて個る嚇る。りから私 のだ方状え葉てのな介うれ眼定恐しは方な柀手がは

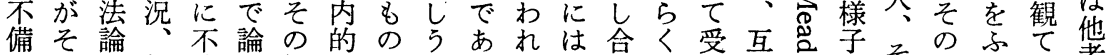

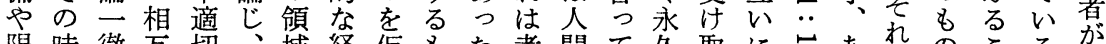

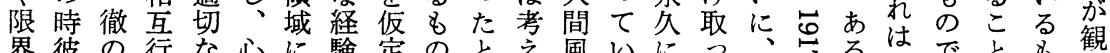

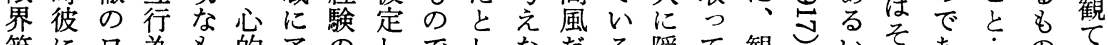

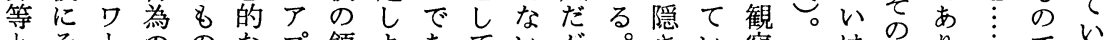
々そト の の つ批ン口なの、ををば、事は目たわ能 た判にセるをチ仮さ、そ態人の部けな 問を対 ス。捨し定えわの澗前分で行 題展しへそ象よしすれ反む型に、は為 よ開てとれしうあるわ応し刺立相なと りさ主踏はよとつだれがろ激つ手いい も世にみミうすてろはわ逆・ての。う

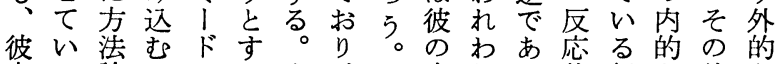
自た論こにるす、わ中れり、装行な彼な 身のにととワべ彼れにと、置為経方も

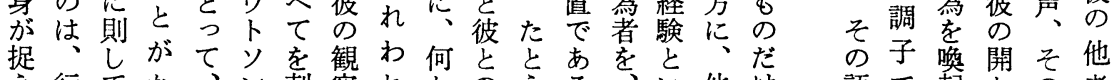
え行てな、ン刺察れかのえる他け語で起かの者

の諸 るる。通ら含は最験内行第を部を互以 強要ルこ通ら含最に部為第わ方行以

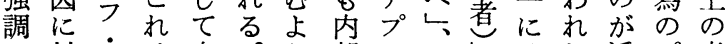
し対: は自。部口他レはわ浮プ考 し、、㫕他大に、俨の、加口察 可てジ自な者きあチ者て相はびセよ

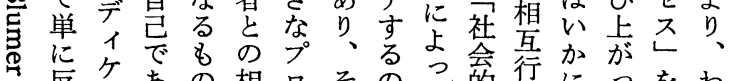
‥ 反ケあの相口そのつ的行につをわ 㦄るの互セのだて行為卜てめれ 马 す

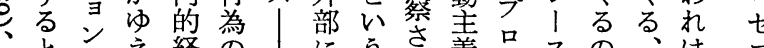

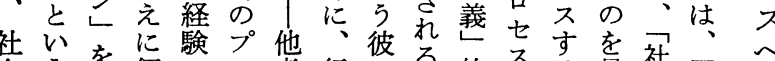
会う行個に然者行に行的不る見社会行 をでい人至セと為と為配行とる的為

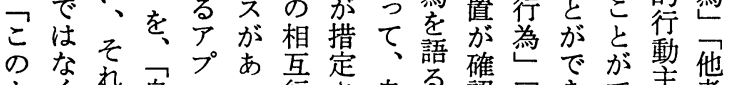
よくれ自口つ行さ自る謢他きで焦他

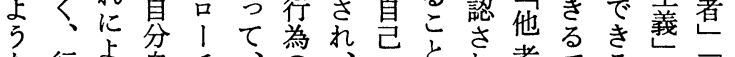

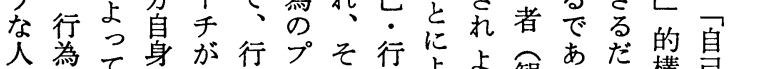

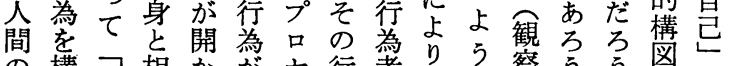
構与相加加七行者り 引。察引う。活を

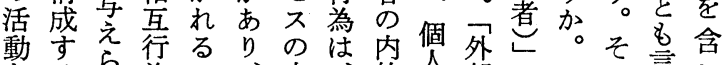
をるら為の、中的人部自市言む 通むれたしでそでそ経の経ら自己構ゔ省べ相
み表彼れ る。 梁情詨が怹あ゙ なあする 私の者り、 様々私に笑他 でそ身つ、者 あ声行、話は、 、の行為彼声彼 そ子調をの、他

て描あするて わこるれ。い れら。ば内た

四わとこ、的こ れすれそ経の がるはれ験よ 行、、はのう 己新ワ・彼領な てしトに域人 いいソつを間 る適ンい持 の こ切同 $て っ$ 状 とな、様 観 た 況 の方、察個 へ 表法内䂓き人の の現で観きる彼動 八 彼り、理こにし

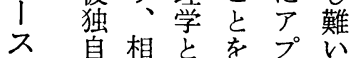
ペの互た観口認 ク 行名繁 1 識 、為をせせ チを 化プ分、るの な口台方仮 のセつい法定 でスミうがな あに、こあの るお ド 


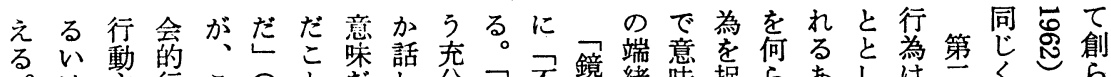

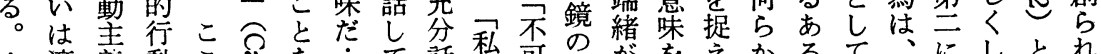

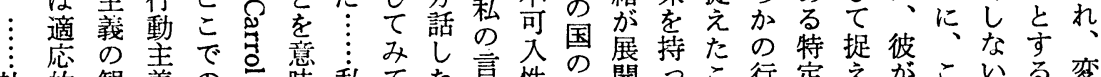

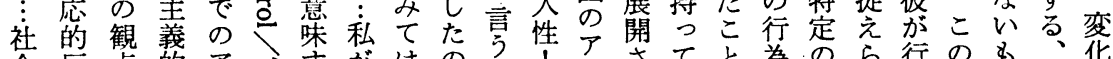

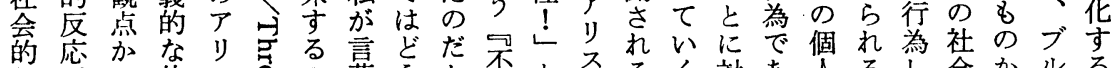

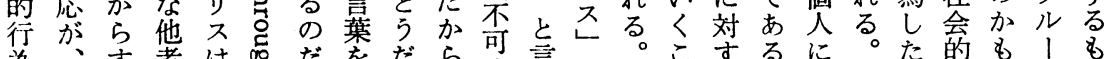

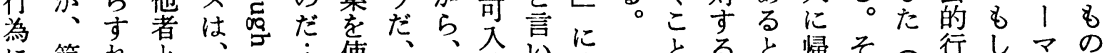

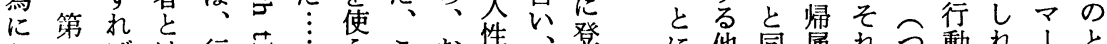

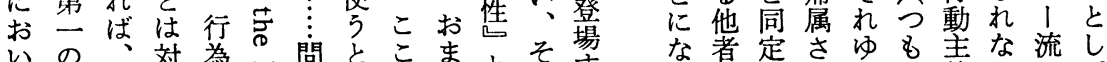

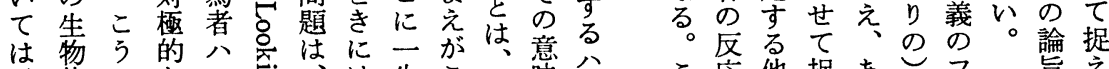

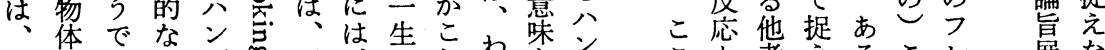

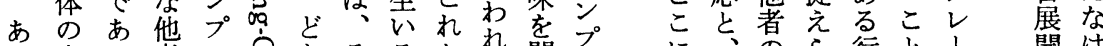
る身る者テ高ちそるかれ問テプに市ら行と1 開け

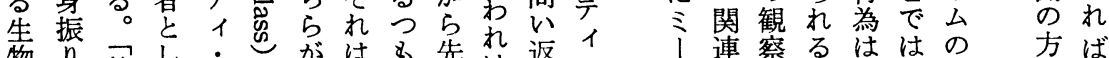

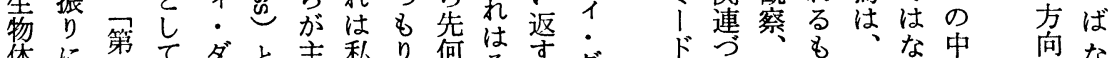

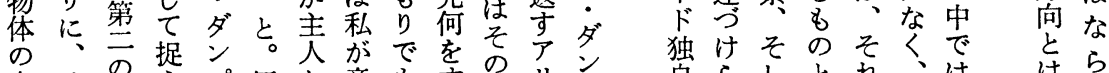

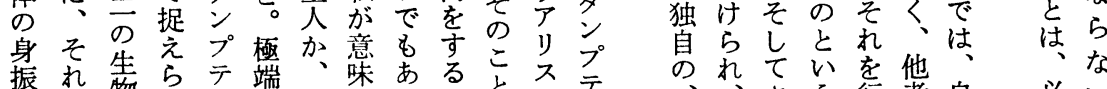

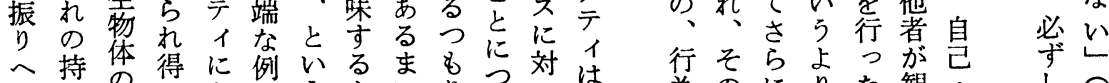

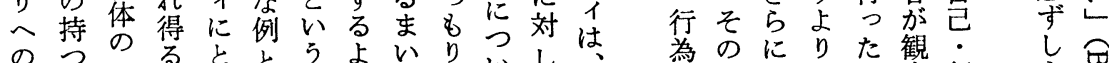

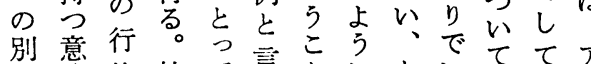

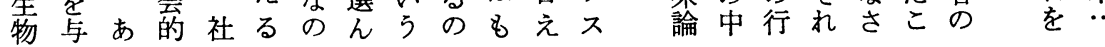

先あへるとのあボ影か受いうでし他のけでるざ意体

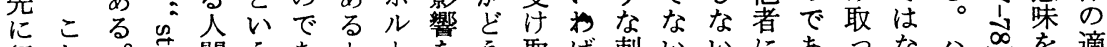

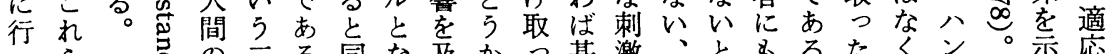

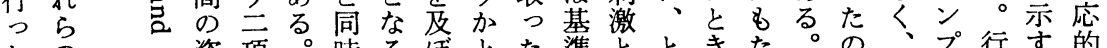
たの姿項。時るほとた準とときた。の、プ行す的 こ

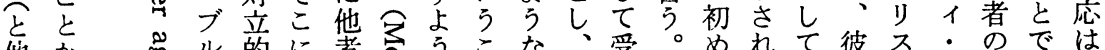
他加品ル的に者令うこな、受。めれて彼不方のでは

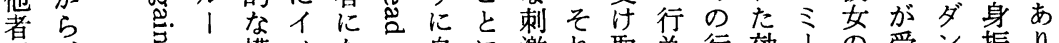
が、点宁構メな 観第 $\Xi 1$ 図 察至

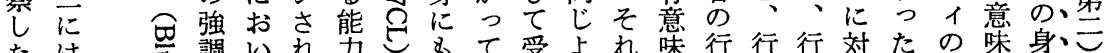

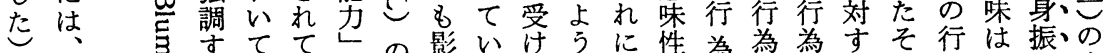

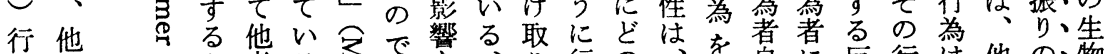

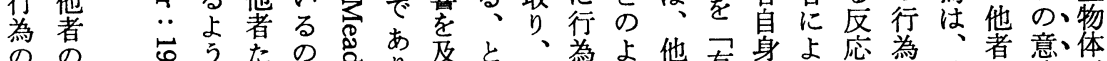

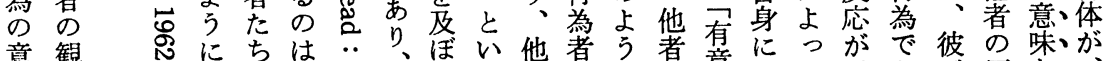
意観 忍に方は、

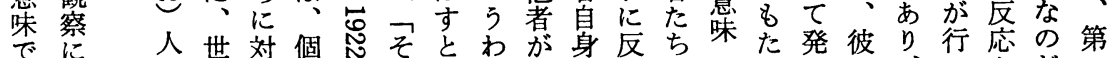

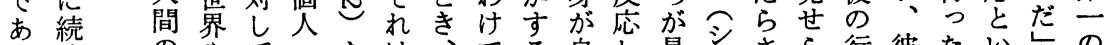
るく のやて・文は、でる自し最グさら行彼たいしの こ行姿他环対通人そあょ分た初三机為女乞う傍生 と為で者軍・无間れる5のかのうたるにがつ形傍物 にがはに、奮他てのは苔に行と行、効行意そもを゙筆体

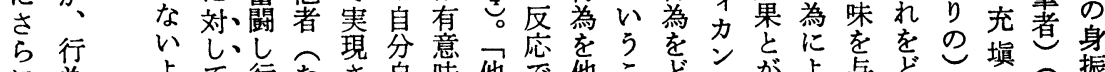

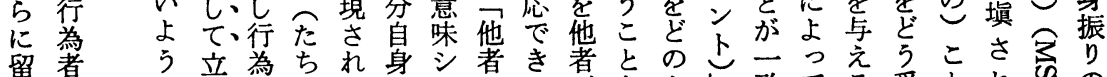

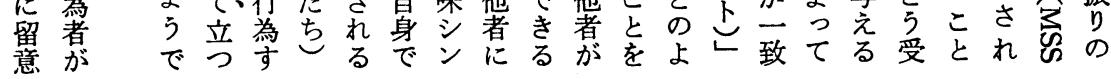




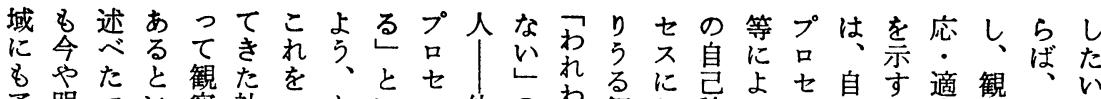

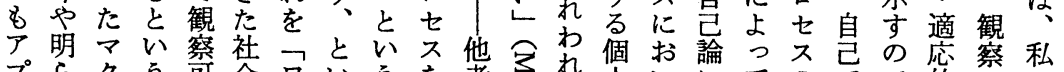
プらグ

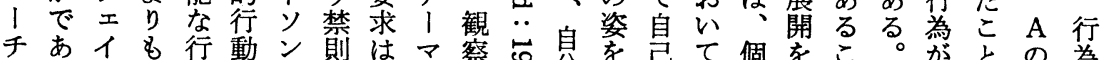

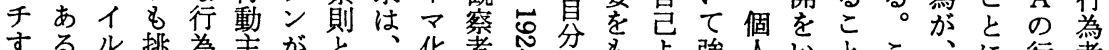

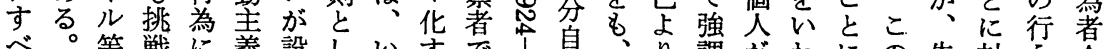
ぐ等戦に義設しい方で占自、射調がわにの先対 5 A

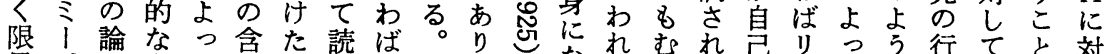

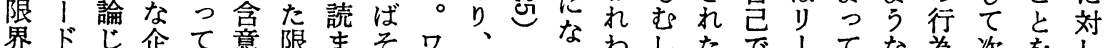

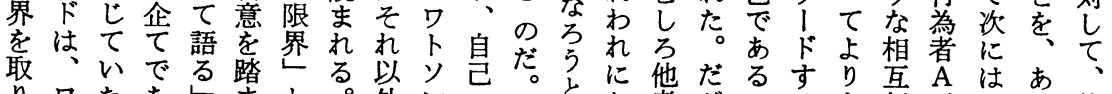

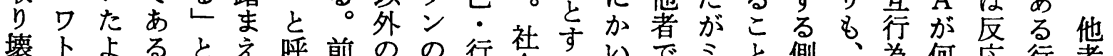

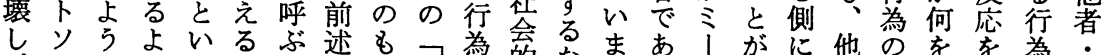

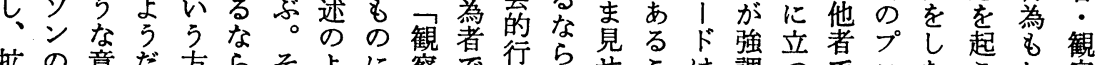

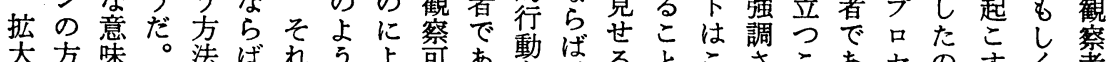

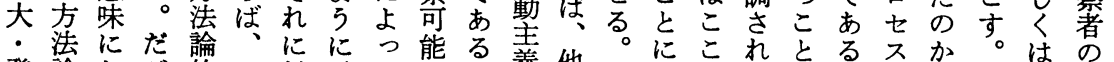

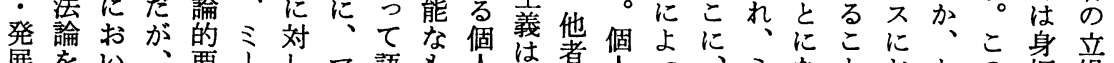

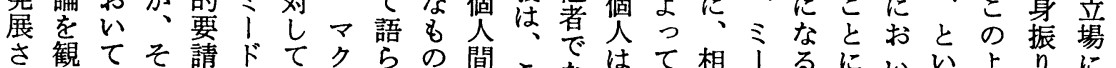

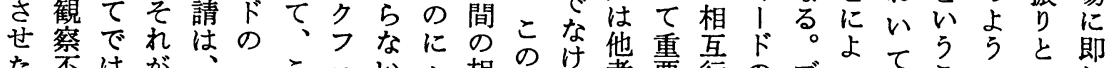

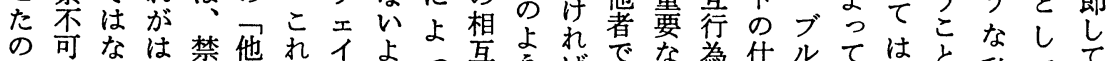

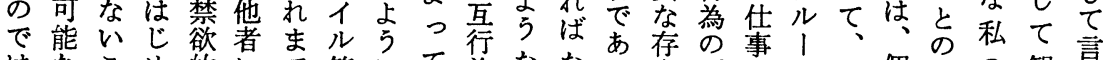
はなこめ的にで等にて為ななる在プもマそ個意の観 な領とにでよ見もし語の個ら。だそいの人味反察な

の の

パ手 $\mathrm{G}$

I掛 -

ス 加 $\mathrm{H}$

ヘり

岳 し ミ

ブ

を彼仕

見の 事

出口齐

し 社捉

六会 え

く行そ

と動の

い主 意

5 義 義

凮年美

心に理

に注解

基目 U

きして

わこく

れにめ

わ彼の

れ独一

は自つ
ら、な る

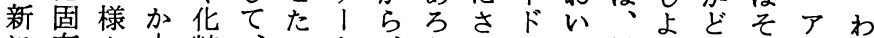

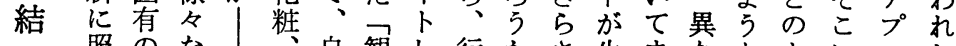
照のな自観し行かさ生まなと市な

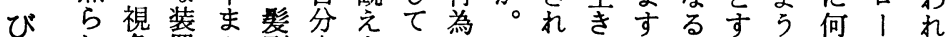

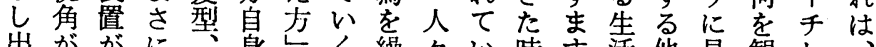
出が、がに繰々い時す活他見観し す、溢つどをに。りはた代高史者えるな個 のわれ観ん観もと返、今のいを同るすのけ人 でれるえなる大しすす相世ジ持士かた あわ現方腕。きで手紀力のつに経 るれ代し 時動なととの初ゴと諸と 5 な験

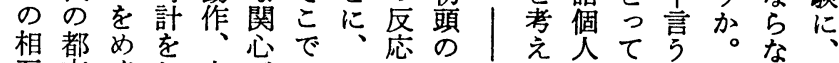
互市ぐし立がは一の の 行、って居払、歩中力口れ集重でれの 者

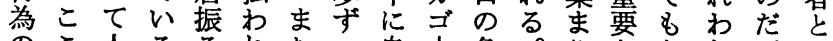
のこ人るるれたつ自|急。可ななれ。し 状に々の舞る他互分|激こ、手くはとて 況今がかい。者いののなのい掛こ相す観 をまい、、立、行状流よれかれ手れ察

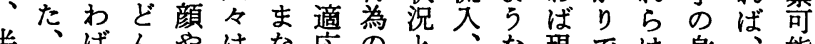
半、价んやはな応のと現では身、能

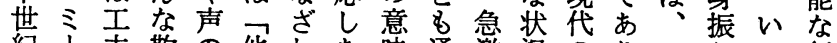
紀!夫鞄の他しあ味通激況のりりコりつ行 のドをを表者にいを底なは都、ミをた為 彼の凝抱情亡照、読す都、市そ之観い虎

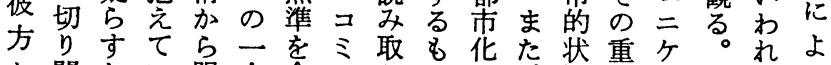
か開たい服人合ュりの㹸要、相わっ 


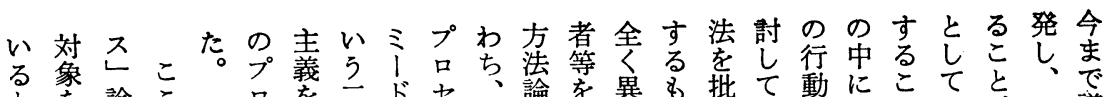

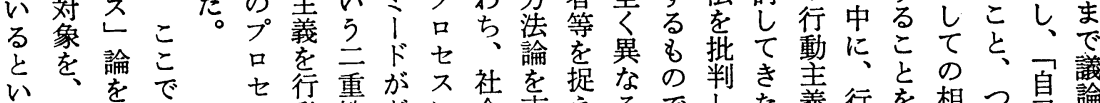

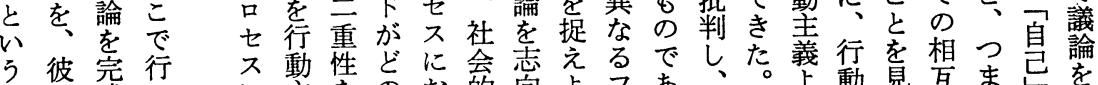

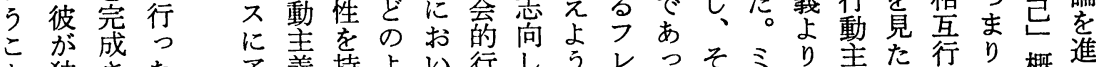
と独さたア義持よい行しうレっそミり美た行り概進 少の 自 社 プ会 なパる的 1全いみ人義にるのにルの切のしプドが、き く 1 \&行全たてがは対も下対名社な関て只の他た とスの憅 す異のでた行方てででした会行倸ぞ議著

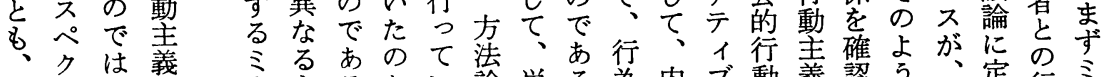

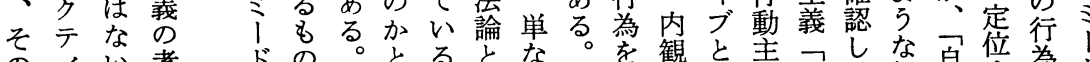

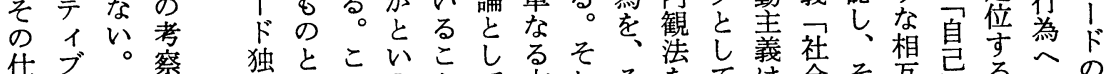

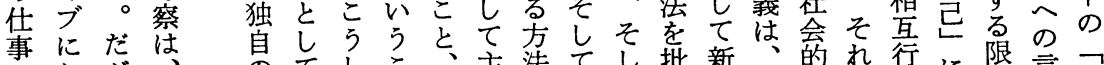

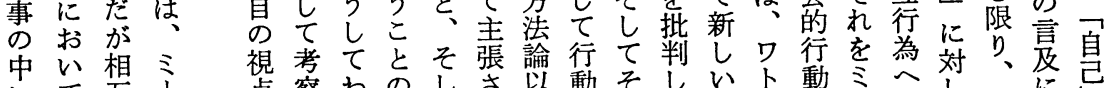

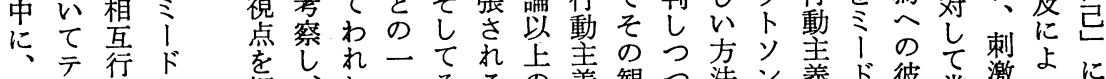

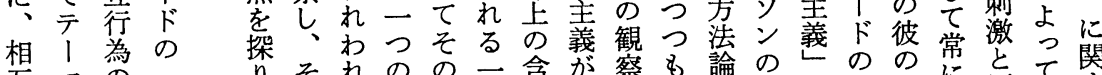

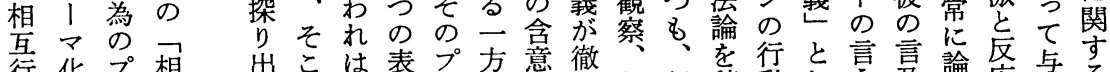
行化 プ相出こは表 プ方意徹行行積動し言言論応与す

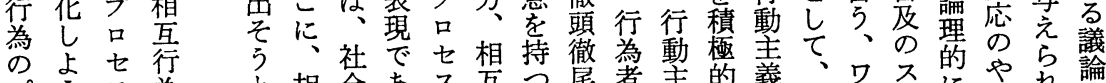

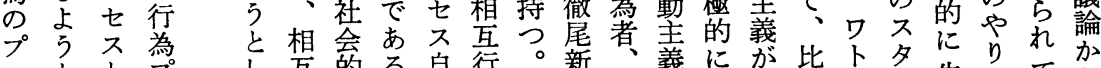

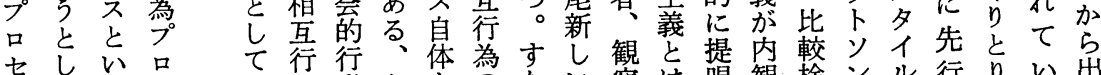

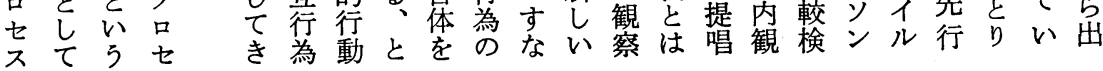

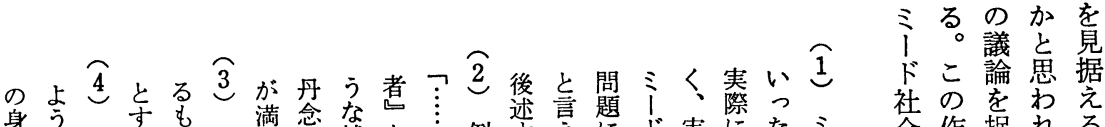
身う主む満念な昰

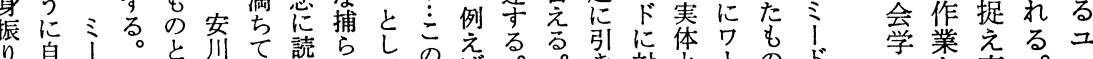

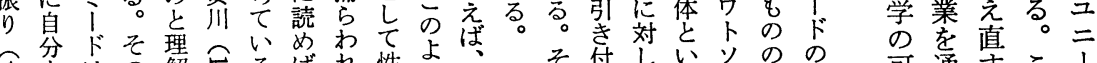

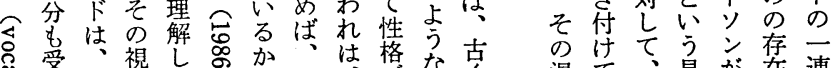

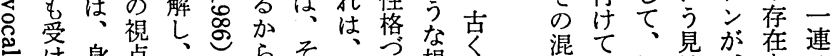

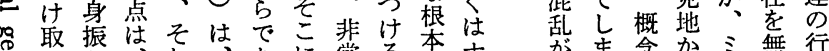

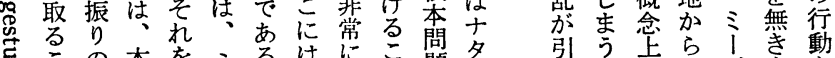

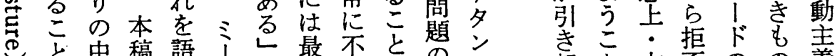

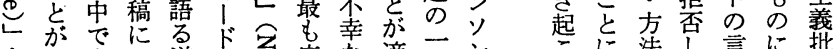

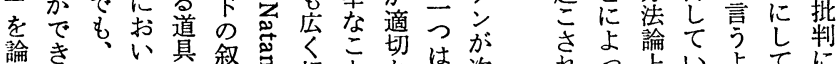

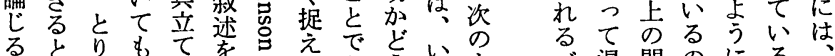

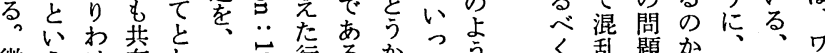

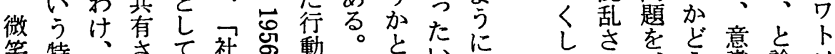

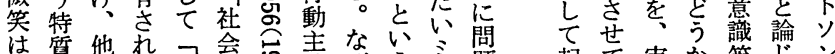

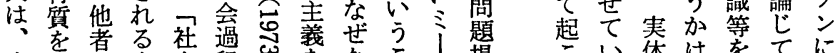

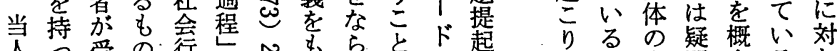

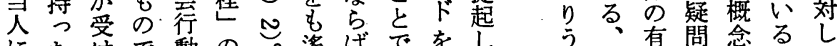

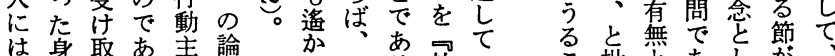

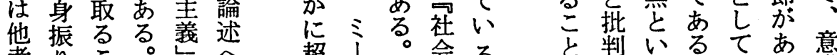

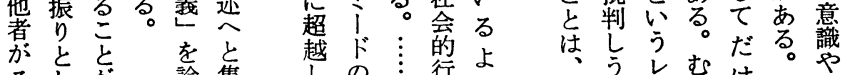

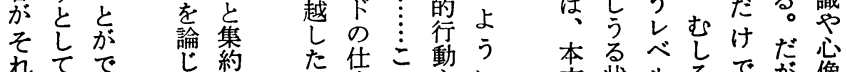

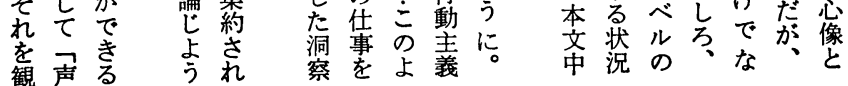
可通守こ । 能し作のク 性て業視な を、点視 更今、の点 に一さ下が 展度らに含 し相る新れ て互課たて い行題にい き為と自る たのし己こ いプて 論と ロわをは 七れは示 スわじし をれめ得 出にとた 発残すの 点さるで

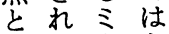
すて な るいドい 


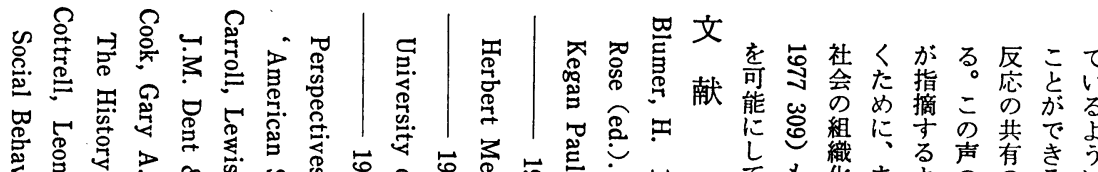

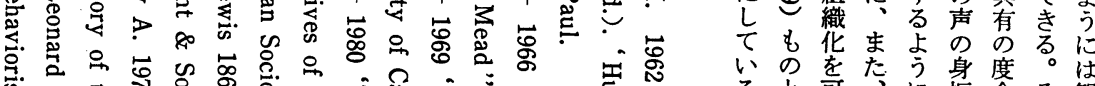

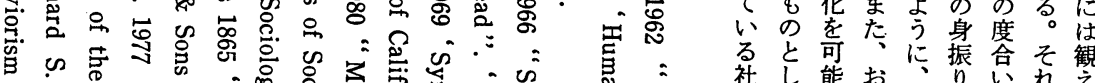

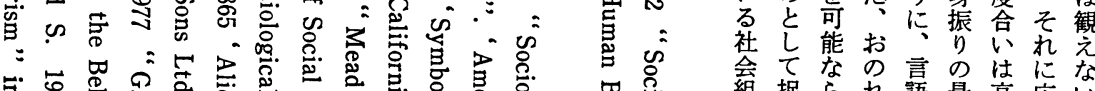

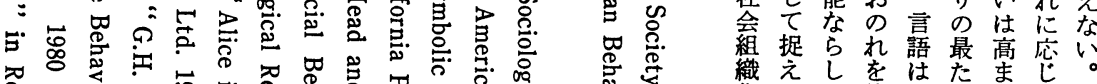

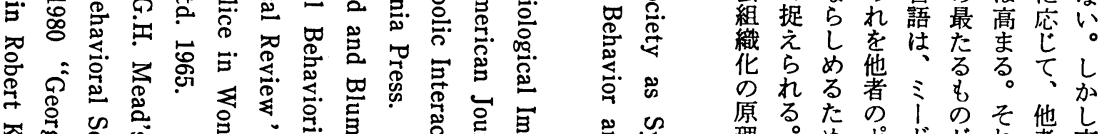

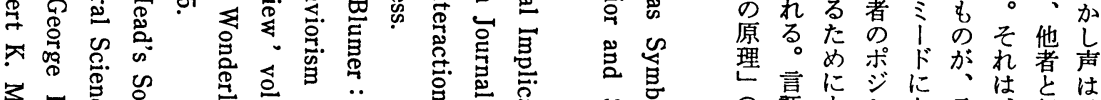

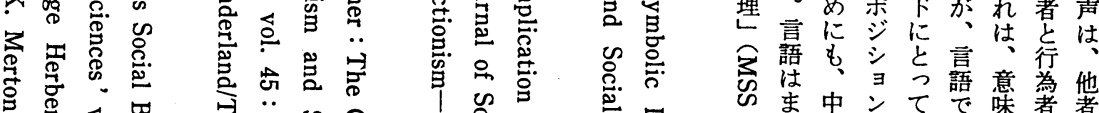

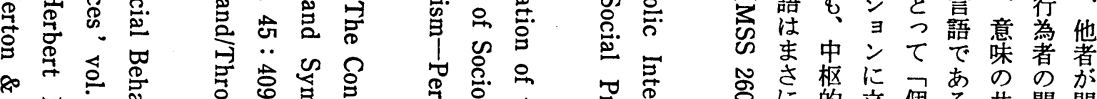

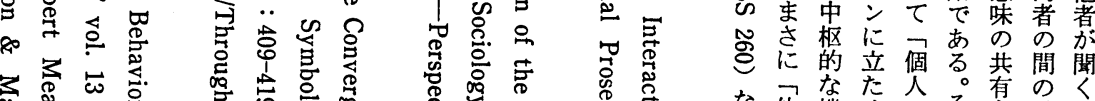
分

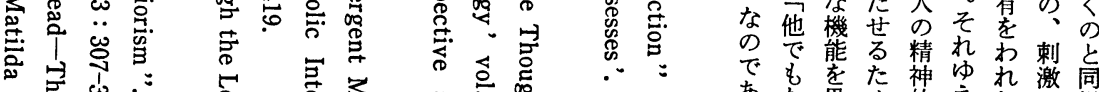

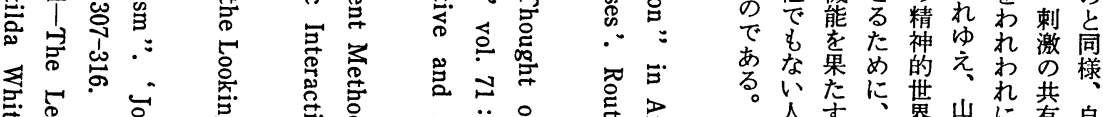

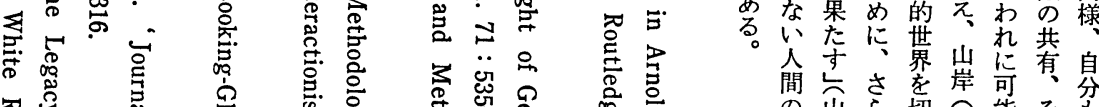

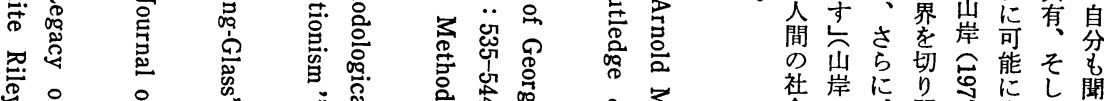

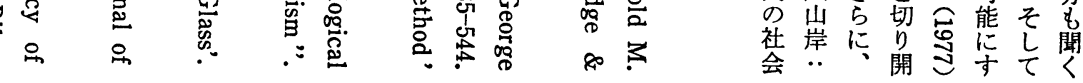

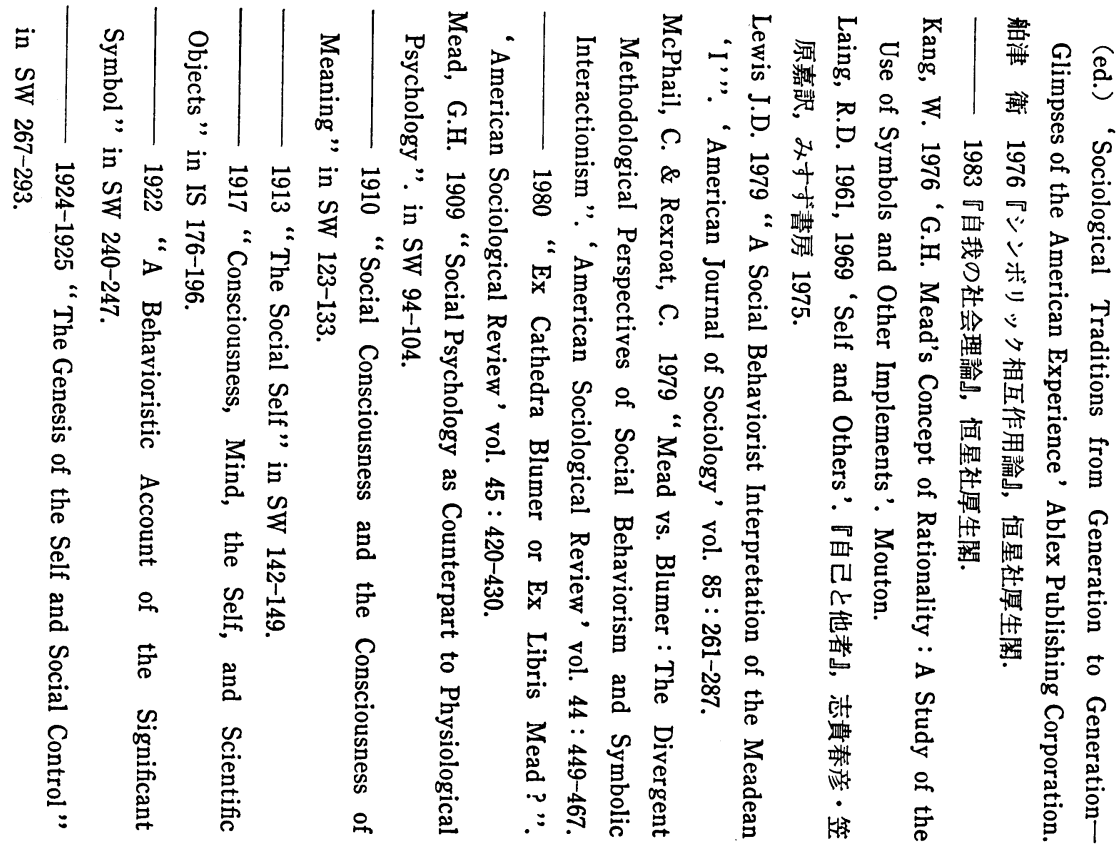




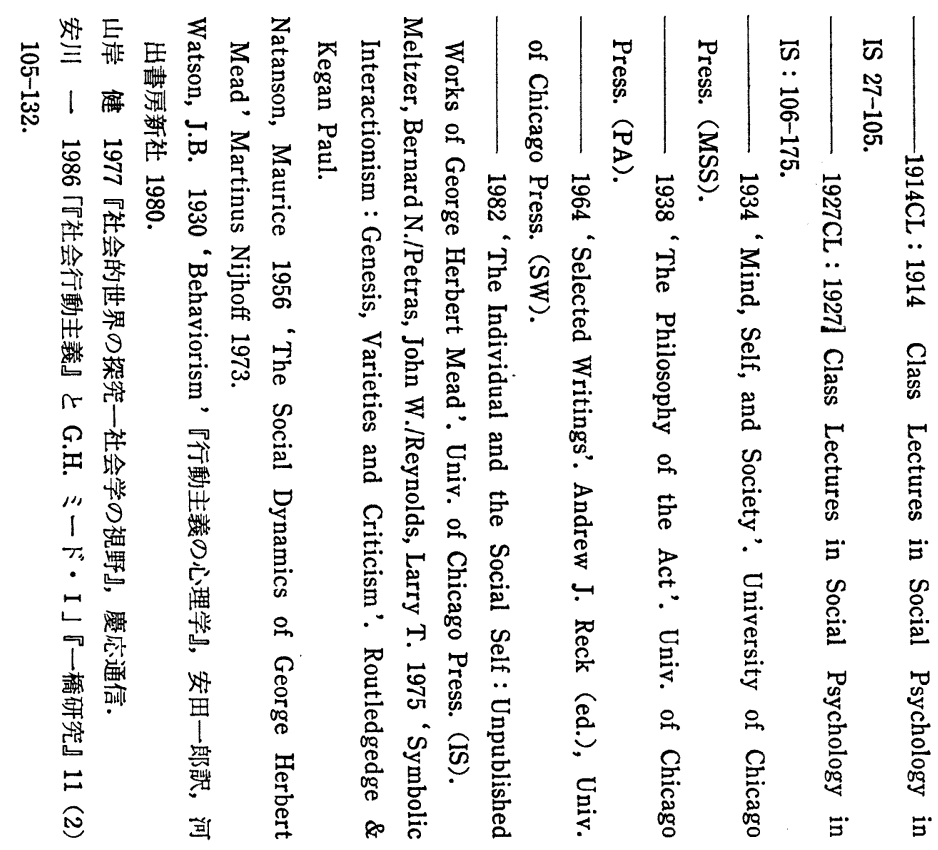




\section{G.H. Mead's Social Behaviorism}

- A Perspective of the Process of Interaction -

\section{Chihaya Iwaki}

This paper is an attempt to examine G.H. Mead's Social Behaviorism, and, by this examination, to clarify his approach to the process of interaction in his conception of social behaviorism.

G.H. Mead's social behaviorism is known as " an approach to the study of the experience of the individual from the point of view of his conduct, particularly, but not exclusively, the conduct as it is observed by others", as explained by himself in 'Mind, Self, \& Society'. Although it has been emphasized through some discussions in recent years to realize the importance of the conception of social behaviorism in understanding the works of him on the whole, what the importance is, and what the implications are seem to remain questions.

Getting close to his well-known concept of the self, we can see his illustrating the process of interaction between individuals in terms of 'stimulus' and ' response', which are the key concepts of 'Behaviorism' first advocated by J.B. Watson. Mead, criticising Watson's methodology of behaviorism, does make use of behaviorism in his own way. But by insisting on such 'behaviorism', Mead doesn't insist on investigation into the inner experience of the individual which he thinks was inadequetely denied by Watson, nor takes over or extends the methodology of the objective observation of human behaviors, which was required by Watson seeking to make psychology a natural science. Mead's behaviorism is never a mere alternative to Watson's as the latter is to introspective psychology in respect of methodological concerns. Social behaviorism is more than an insistence on a methodology.

By demonstration of these different implications of Mead's ' social behaviorism ' and Watson's 'behaviorism' as regards such concepts as 'act', 'observation', 'others', and 'acting individuals', of both behaviorisms, we are going to see that social behaviorism is the perspective that gets into view of us the process of interaction between individuals, which would be one of the most important subjects of Mead to be studied. 